\title{
LAS ESPECIES EXÓTICAS INVASORAS Y EL DERECHO, CON ESPECIAL REFERENCIA A LAS ESPECIES ACUÁTICAS, LA PESCA RECREATIVA Y LA ACUICULTURA
}

\author{
PEDRo BRUfao CURIEL \\ Catedrático de Escuela Universitaria interino de Derecho Administrativo \\ Universidad de Extremadura \\ pbrufao@unex.es
}

Recibido: 9 de abril de 2012 / Aceptado: 7 de junio 2012

RESUMEN: Las especies exóticas invasoras constituyen, según el Programa de las Naciones Unidas para el Medio Ambiente, la segunda amenaza más grave para la biodiversidad, lo cual es además un importante riesgo social y económico. En este trabajo se exponen tanto en el plano internacional como en el europeo y en el nacional los distintos elementos de un consolidado régimen jurídico en pro del mantenimiento y la recuperación de la biodiversidad propia de cada ecosistema. Se exponen así no solo las principales normas, sino también la jurisprudencia recaída y la práctica administrativa al respecto, haciendo un especial hincapié en las especies invasoras propias de los ecosistemas acuáticos, dado que son estos de los más perjudicados a escala global. Este trabajo huye de la mera relación sucinta y formalista de las normas, a la vez que se apoya en estudios científicos contrastados para someter a crítica los fallos actuales y subraya los pasos bien encaminados que pueden ayudar a nuestra maltrecha biodiversidad.

RESUM: Les espècies invasores constitueixen, segons el Programa de les Nacions Unides per al Medi Ambient, la segona amenaça més greu per a la biodiversitat, la qual cosa és, a més, un important risc social i econòmic. En aquest treball s'exposen tant en el pla internacional com en l'europeu i en l'estatal les diferents elements d'un règim jurídic consolidat en pro del manteniment i la recuperació de la biodiversitat pròpia de cada ecosistema. S'exposen, així, no només les normes principals, sinó també la 
jurisprudència en relació amb això, així com la praxi administrativa, tot fent un èmfasi especial en les espècies invasores pròpies dels ecosistemes aquàtics, atès que aquests es troben entre els més perjudicats a escala global. Aquest treball intenta fugir d'una mera relació succinta i formalista de les normes, a la vegada que recolza en estudis científics contrastats per sotmetre a crítica els errors actuals i subratlla les passes ben encaminades que podrien ajudar a la nostra biodiversitat malmesa.

ABSTRACT: Invasive alien species are, according to the United Nations Environmental Program, the second most serious threat to biodiversity, which is also an important social and economic risk. This work presents at international, European and Spanish level the various elements of a consolidated law for the maintenance and recovery of the biodiversity of each ecosystem. This paper does not only try to present the main rules, but also the case-law and administrative practice in this regard, with a particular emphasis on the invasive species in aquatic ecosystems, given that they pose the worst problems at global scale. This paper steers clear of a mere formalistic and succinct exposure of standards, relying instead on scientific studies to build a critique of the current failures, underlining the steps that can help our ailing biodiversity.

PALABRAS CLAVE: Especies exóticas invasoras - pesca - acuicultura biodiversidad.

PARAULES CLAU: Espècies exòtiques invasores - pesca - aqüicultura biodiversitat.

KEYWORDS: Invasive alien species — fishing — aquaculture — biodiversity.

Sumario: I. Introducción. II. Las especies exóticas invasoras en el Derecho Internacional. 1. Las especies exóticas invasoras en el Convenio de la Biodiversidad: La biodiversidad autóctona como bien jurídico. 2. La regulación de las especies exóticas invasoras en otros instrumentos internacionales, con especial referencia a su comercio. III. La protección de la biodiversidad autóctona frente a las especies exóticas invasoras en la UE: su evolución legal y jurisprudencial bajo el principio de precaución. IV. El régimen jurídico y la gestión de las especies exóticas invasoras en España. 1. La normativa de pesca fluvial como ilícito apoyo público a la expansión de especies exóticas invasoras. 2. El cambio de rumbo en la protección jurídica de la biodiversidad autóctona. 3. El Real Decreto de Especies Exóticas Invasoras 
y la disputa sobre las especies ícticas, la pesca recreativa y la acuicultura. V. Conclusiones. VI. Bibliografía.

\section{INTRODUCCIÓN}

El Programa de las Naciones Unidas sobre Medio Ambiente (PNUMA) califica el problema de las invasiones biológicas como una de las cinco causas principales de pérdida de la biodiversidad, junto con la destrucción del hábitat, el cambio climático, la sobreexplotación y la contaminación ${ }^{1}$. Las invasiones biológicas son también un grave problema económico, pues se calcula que ocasionan al menos unas pérdidas globales de 1'4 billones de dólares norteamericanos al año, según el PNUMA², especialmente en los ecosistemas acuáticos continentales, dada la facilidad que muestran ríos y humedales para las expansiones biológicas, así como en los ecosistemas insulares.

Teniendo en cuenta estas apreciaciones, avaladas por numerosos estudios científicos, el PNUMA estableció el control de las amenazas planteadas por las especies biológicas como uno de los objetivos para lograr la protección de la biodiversidad para el año 2010. Este objetivo general de control se ha dividido en dos cuestiones. Por un lado, el control de las rutas de las principales especies exóticas invasoras (EEI), respecto del cual se dice que "no se ha alcanzado a nivel mundial ya que persiste la invasión de especies exóticas como consecuencia del incremento del transporte, el comercio y el turismo. Sin embargo, las acciones nacionales emprendidas en el marco de acuerdos mundiales sobre protección fitosanitaria y agua de lastre han logrado contener significativamente la invasión de nuevas especies en algunos países y ecosistemas”. Por otro lado, se habla de aplicar planes de gestión para las principales especies exóticas que amenazan los ecosistemas, hábitats o especies, lo cual "no se ha alcanzado a nivel mundial, aunque existen algunos planes de manejo", pues "la mayoría de los países no tiene programas efectivos de ese tipo"3, constatándose los crecientes riesgos que suponen las especies exóticas invasoras ${ }^{4}$ y las patentes mejoras de la calidad de la

\footnotetext{
${ }^{1}$ Secretaría del Convenio sobre Biodiversidad (2010): Perspectiva mundial sobre la diversidad biológica 3 , Montreal.

${ }^{2}$ Ibíd., pág. 6. Sobre las aproximaciones económicas de la biodiversidad, vid. TEEB, The Economics of ecosystems and biodiversity for national and international policy makers, Earthscan, Londres, 2011.

${ }^{3}$ Ibíd., pág. 18.

${ }^{4}$ Ibíd., pág. 64: "En una muestra de 57 países, se encontraron más de 542 especies exóticas cuyas repercusiones en el medio ambiente se han comprobado, entre ellas plantas vasculares, peces marinos y de agua dulce, mamíferos, aves y anfibios, con un promedio de más de 50 de esas especies por país (y una variación que va de nueve a más de 220). Sin duda se trata de una subestimación, porque excluye muchas
} 
biodiversidad cuando se interviene a tiempo para lograr su erradicación o al menos su control $^{5}$. Con estos antecedentes en mente y con vistas a ayudar a entender este relativamente nuevo campo del Derecho Ambiental ${ }^{6}$, el estudio que el lector tiene en sus manos analiza las principales cuestiones jurídicas que suscitan las especies exóticas invasoras, tanto en el plano del Derecho internacional como en el comunitario europeo y el nacional, con especial referencia a las especies ícticas, la pesca y la acuicultura, sectores donde los efectos de las EEI son particularmente notorios.

\section{LAS ESPECIES EXÓTICAS INVASORAS EN EL DERECHO INTERNACIONAL}

\section{Las especies exóticas invasoras en el Convenio de la Biodiversidad: La biodiversidad autóctona como bien jurídico}

Con algunas normas pioneras como la Convención de Bucarest referente la pesca en las aguas del Danubio, de 28 de enero de 1958, cuyo art. 10 del anexo exigía la autorización previa de la Comisión Mixta para la aclimatación y cría de nuevas especies

especies exóticas cuyo impacto no se ha estudiado aún y comprende países sobre los cuales no se dispone de datos respecto de las especies exóticas. Es difícil saber con precisión si está aumentando el daño causado por esta fuente, dado que en muchas zonas empezó a prestarse atención al problema hace poco, por lo que las mayores repercusiones de las especies invasoras puede reflejar, en parte, el conocimiento más exacto y la mayor conciencia del tema. Sin embargo, en Europa, donde se han introducido especies exóticas durante muchos decenios, el número acumulativo sigue aumentando y así ha sucedido al menos desde principios del siglo XX. Aunque no sean necesariamente invasoras, mientras más especies exóticas haya en un país, mayor es la posibilidad de que se conviertan en invasoras. Se ha estimado que de cerca de 11.000 especies exóticas en Europa, una de cada diez tiene impactos ecológicos y una proporción ligeramente mayor produce daños económicos".

5 Tal y como afirma el PNUMA: "Principalmente gracias al control o la erradicación efectiva de las especies exóticas invasoras, desde 1988 se redujo el riesgo de extinción de once especies de aves, desde 1996 cinco de mamíferos y desde 1980 una de anfibios. De no haber sido por esas medidas, se estima que las especies de aves hubieran tenido, en promedio y según mediciones del Índice de la Lista Roja, un 10\% menos de probabilidades de sobrevivir y los mamíferos casi un 5\% menos. Sin embargo, ese índice también muestra que se ha deteriorado el estado de conservación de casi el triple de aves, casi el doble de mamíferos y más de 200 veces la cantidad de especies de anfibios, principalmente debido a una mayor amenaza de animales, plantas o microorganismos invasores. En líneas generales, las especies de aves, mamíferos y anfibios se encuentran hoy más amenazadas, en promedio, por la invasión de especies exóticas. Si bien no se ha evaluado exhaustivamente otros grupos, se sabe que las especies invasoras son la segunda causa más importante de extinción de los mejillones de agua dulce y más generalmente de las especies endémicas. Ibíd., pág. 65.

${ }^{6}$ Sobre las cuestiones generales del Derecho de la Biodiversidad, vid. SORIANO GARCÍA, J. E. y BRUFAO CURIEL, P., Claves de Derecho Ambiental II. Medio natural, biodiversidad y riesgos tecnológicos, Iustel, Madrid, 2011. También puede consultarse SHINE C., WILLIAMS, N. y BURHENNE-GUILMIN, F., "Legal and institutional frameworks for invasive alien species", Mooney, H.A., J. McNeely, L.E. Neville, P.J. Schei, J.K. Waage (eds.), Invasive Alien Species: a new synthesis, Island Press, Washington DC, 2005. ALLI TURRILlAS, J. C., La protección jurídica de la biodiversidad, Montecorvo, Madrid, 2008. 
de peces, animales y plantas acuáticos, la principal norma internacional sobre las EEI es el Convenio sobre la Diversidad Biológica de 1992 (CDB).

El CDB recoge diversas medidas de conservación "in situ" destinadas a la mejora de la biodiversidad en su art. 8, entre las cuales se encuentra en su apartado h) el que cada Parte contratante, en la medida de lo posible y según proceda, “impedirá que se introduzcan, controlará o erradicará las especies exóticas que amenacen a ecosistemas, hábitats o especies". Es decir, trata de ir a la causa de los perniciosos efectos ocasionados por las especies exóticas invasoras empezando por evitar su introducción; si ésta ya se ha producido, las Partes contratantes se obligan a instar su control, lo que de suyo implica el que no se liberen más ejemplares de una especie, subespecies, población o raza concreta y con vistas a evitar su propagación, teniendo en cuenta además el compromiso de la erradicación y los verbos empleados en dicho art. 8 h), que denotan una clara obligación de resultado para los Estados signatarios ${ }^{7}$.

Dada su importancia, la Secretaría del CBD cuenta con un programa horizontal sobre especies exóticas invasoras, cuyos elementos principales han sido desarrollados por la $6^{\mathrm{a}}$ Conferencia de las Partes (COP6) de abril de 2002, cuya Decisión VI/23 toma nota del Informe del año 2001 sobre el estado, los impactos y las tendencias de las especies exóticas que amenazan los ecosistemas, los hábitats y las especies ${ }^{8}$, por el que afirma que "las especies exóticas invasoras representan una de las principales amenazas a la diversidad biológica" y reconoce la labor llevada a cabo en cumplimiento de instrumentos internacionales como el Convenio Internacional de Protección Fitosanitaria, la Oficina Internacional de Epizootias, las organizaciones regionales de protección de las plantas, la FAO, la OMI y la OMS. Esta COP6 se apoya en varias cuestiones básicas para urgir a las Partes contratantes la adopción de medidas, que son ${ }^{9}$ : Estrategias y planes de acción nacionales en materia de especies exóticas invasoras destinadas a determinar las necesidades nacionales y la cooperación internacional, así como la evaluación, la información y el empleo de instrumentos adecuados.

\footnotetext{
${ }^{7}$ Sobre el CDB y las especies invasoras pueden consultar esta página de Internet: www.cbd.int/invasive. Sobre los diferentes métodos y modelos para cumplir los diferentes Tratados sobre biodiversidad, es imprescindible la consulta de www.tematea.org. "Tematea", un programa conjunto de la UICN y el PNUMA, cuenta con una sección específica sobre especies invasoras.

8 "Status, impacts and trends of alien species that threaten ecosystems, habitats and species", con la referencia UNEP/CBD/SBSTTA/6/INF/11, de 26 de febrero de 2001.

${ }^{9}$ Decisión VI/23. La Haya, 7 - 12 de abril de 2002.
} 
Quizás lo más importante de este documento del COP6 es el anexo sobre los "principios de orientación para la prevención, introducción y mitigación de impactos de especies exóticas que amenazan los ecosistemas, los hábitat o las especies", siendo el primero de ellos el principio de precaución ${ }^{10}$ frente a las introducciones intencionales o no intencionales, así como respecto de los proyectos de erradicación ${ }^{11}$, contención y control, subrayándose el hecho de que la falta de certidumbre científica acerca de las diversas consecuencias de una invasión no debería utilizarse como una razón para aplazar o para no adoptar medidas adecuadas de erradicación, contención y control. La adopción de este principio de precaución conlleva el que se realice desde el punto de vista del ecosistema y con la prioridad de prevenir la entrada de las EEI, entre los Estados y dentro de un Estado, con el control fronterizo y las medidas de cuarentena y el intercambio de información basándose en la cooperación internacional. Si ya se ha producido la entrada de una especie invasora, una pronta detección y una acción rápida son decisivas para impedir su establecimiento.

Según el COP6 la respuesta preferida es erradicar los organismos tan pronto como sea posible, mientras que solo en el caso de que no sea posible o que no se disponga de recursos para su erradicación, deberían aplicarse medidas de contención y control a largo plazo, debiendo realizarse el examen de los beneficios y de los costos ambientales, económicos y sociales. Asimismo, los Estados deberían reconocer el riesgo que pueden plantear las actividades realizadas bajo su jurisdicción o control para otros Estados si son una fuente potencial de EEI, y deberían adoptar las medidas individuales o en cooperación adecuadas para reducir al mínimo ese riesgo, incluyendo el suministro de cualquier información. Para ayudar a los Estados a reducir al mínimo la propagación y efectos de las especies exóticas invasoras, deberían identificar, en la medida de lo posible, las especies que podrían convertirse en invasoras y poner esa información a disposición de otros países, como los estudios taxonómicos básicos de la diversidad biológica, a lo que se suma la adecuada vigilancia de nuevas especies exóticas invasoras, vigilancia que debería incluir estudios concretos y generales, y aprovechar la participación de otros sectores, con inclusión de las comunidades locales. La

\footnotetext{
${ }^{10}$ Principio 15 de la Declaración de Río sobre Medio Ambiente de 1992.

${ }^{11}$ YOUNG, T. R., National and regional legislation for promotion and support to the prevention, control and erradication of invasive species, World Bank, Biodiversity Series, núm. 108, Washington DC, 2006.
} 
investigación sobre una especie exótica invasora debería incluir un examen cuidadoso y debería documentar la historia y la ecología de la invasión (orígenes, vías y períodos), las características biológicas de la especie exótica invasora y los correspondientes impactos en el ecosistema, las especies y el nivel genético, y también los impactos sociales y económicos y la forma en que cambian a lo largo del tiempo, con el debido conocimiento de estas cuestiones por parte de la sociedad.

Como es obvio, no debería haber ninguna primera introducción intencional o introducciones ulteriores de EEI en un país sin la autorización previa de una autoridad competente del Estado receptor, debiéndose efectuar un análisis de riesgos adecuado, que podría incluir una evaluación del impacto en el medio ambiente, como parte del proceso de evaluación antes de llegar a una decisión respecto de si ha de autorizarse o no una introducción propuesta al país o a nuevas zonas ecológicas dentro de un país. En cualquier caso, la carga de la prueba de que es improbable que una introducción propuesta amenace la diversidad biológica debe corresponder al proponente o ser asignada, según proceda por el Estado receptor. La autorización de una introducción puede ir acompañada, cuando proceda, de condiciones como la preparación de un plan de mitigación, la adopción de procedimientos de vigilancia, el pago por evaluación y gestión o los requisitos de contención.

En cuanto a las introducciones no intencionales ${ }^{12}$, los Estados han incluir medidas legales y reglamentarias y el establecimiento o fortalecimiento de instituciones y organismos con las correspondientes responsabilidades, señalándose las vías comunes que llevan a este tipo de introducciones no intencionales y adoptándose las disposiciones adecuadas para reducirlas a un mínimo, así como la evaluación del impacto ambiental de esas actividades y sus riesgos.

El COP6 establece asimismo que una vez detectado el establecimiento de una especie exótica invasora, los Estados, de forma individual y en cooperación, deberían adoptar medidas tales como la erradicación, la contención y el control para mitigar los efectos perjudiciales, teniendo en cuenta que las técnicas utilizadas para la erradicación, contención o control deben ser inocuas para los seres humanos, el medio ambiente y la

12 Suelen ser: la pesca, la agricultura, la silvicultura, la horticultura, el transporte marítimo incluida la descarga de aguas de lastre, el transporte de superficie y aéreo, los proyectos de construcción, la ordenación de paisajes, la acuicultura, incluida la acuicultura de tipo ornamental, el turismo, la industria de animales domésticos y los cotos de caza. 
agricultura, a lo que se unen consideraciones éticas para los interesados de las zonas afectadas. En todo caso, deberían adoptarse medidas de mitigación en la primera etapa posible de la invasión, sobre la base del enfoque de precaución y aplicando la recuperación de los costes a la persona o entidad responsable de la introducción de las especies exóticas invasoras en cuestión.

Acerca de la erradicación, hay que subrayar el que se prefiera este método por la Convención de la Biodiversidad. En efecto, siempre que sea posible, se afirma que "la erradicación es a menudo la mejor medida para hacer frente a la introducción y al establecimiento de especies exóticas invasoras", contando con mayores garantías de éxito en las primeras etapas de la invasión, cuando las poblaciones son pequeñas y están localizadas, teniéndose en cuenta los efectos secundarios sobre la diversidad biológica.

Cuando la erradicación no es apropiada, la contención o limitación la propagación de especies exóticas invasoras es a menudo una estrategia adecuada en los casos en que el ámbito de los organismos o de una población es suficientemente pequeño para hacer factibles estos esfuerzos. Por su lado, las medidas de control deberían concentrarse en reducir el daño causado y en la reducción del número de EEI. Un control eficaz dependerá con frecuencia de toda una serie de técnicas integradas de ordenación, con inclusión del control mecánico, químico, biológico y ordenación de los hábitats, ejecutadas con arreglo a los reglamentos nacionales y códigos internacionales existentes. Para terminar, la $10^{\mathrm{a}}$ Conferencia de las Partes del CDB adoptó el Plan Estratégico para la Biodiversidad 2011-2020, en el marco de las "20 Metas de Aichi para la Diversidad Biológica”. En concreto, la Meta $n^{\circ}$ 9, dedicado a las especies invasoras, establece que en el año 2020 "se habrán identificado y priorizado las especies exóticas invasoras y vías de introducción" y además "se habrán establecido medidas para gestionar las vías de introducción a fin de evitar su introducción y establecimiento".

\section{La regulación de las especies exóticas invasoras en otros instrumentos internacionales, con especial referencia a su comercio}

Otras de las normas internacionales aplicables es el Convenio de Bonn sobre la conservación de las especies migratorias de animales silvestres, de 23 de julio de 1979, que trata en esta fecha tan lejana la importante cuestión de las EEI. En concreto, dedica parte de su art. V a las directivas sobre acuerdos internacionales, respecto de lo cual 
añade en su apartado 5 e) que todo Acuerdo entre los Estados signatarios en la medida en que sea adecuado y posible, debería prever, sin limitarse sin embargo a esto, lo siguiente: "la conservación y, cuando sea necesario y posible, la restauración de los hábitats que sean importantes para el mantenimiento de un estado de conservación favorable, y la protección de dichos hábitats contra perturbaciones incluido el estricto control de la introducción de especies exóticas nocivas para la especie migratoria en cuestión, o el control de tales especies ya introducidas". Esto es, reconoce ya la importancia de la cuestión y fomenta el que se tomen medidas contra las invasiones biológicas, lo que incluye de suyo, como es obvio, el que cese el apoyo público y privado a su expansión, una muestra más de este acervo o corpus jurídico internacional, así como una práctica legal y consuetudinaria internacional, a favor de la biodiversidad y en contra de las EEI que sin duda está plenamente aceptado ${ }^{13}$, que obviamente informa y obliga en este sentido a las decisiones judiciales, la normativa nacional y a la práctica de los poderes públicos y los particulares, cuestión que se refuerza con lo estipulado en el art. III. 4 c) ${ }^{14}$.

Otra fuente del Derecho internacional con importancia sobre especies exóticas y en vigor en España es el Convenio de Berna del Consejo de Europa sobre la conservación de la vida silvestre y el medio natural en Europa, de 19 de septiembre de 1979. Su artículo 11.2 establece de modo asertivo que cada Parte "deberá controlar estrictamente la introducción de especies exóticas". El desarrollo del Convenio de Berna cuenta con una amplia y detallada serie de trabajos sobre las especies invasoras, como la Recomendación 57, de 5 de diciembre de 1997, sobre la introducción de organismos no nativos en el medio ambiente; la Recomendación 91, de 5 de diciembre de 2002, sobre las EEI que amenazan la biodiversidad en islas y en ecosistemas aislados; la Recomendación 77, de 3 de diciembre de 1999, sobre la erradicación de vertebrados terrestres no nativos ${ }^{15}$; la Recomendación 99 , de 1 de diciembre de 2003, sobre la

\footnotetext{
${ }^{13}$ Vi. Art. 96 de la Constitución Española y el art. 1.5 del Código Civil.

14 "Las Partes que sean Estados del área de distribución de una especie migratoria que figura en el Apéndice I se esforzarán por...prevenir, reducir o controlar, cuando sea posible y apropiado, los factores que actualmente ponen en peligro o implican el riesgo de poner en peligro en adelante a dicha especie, inclusive controlando estrictamente la introducción de especies exóticas, o vigilando o eliminando las que hayan sido ya introducidas". Los Apéndices han sido objeto de diversas modificaciones, la última de las cuales tiene por fecha el 23 de febrero de 2012.

${ }^{15}$ Recomienda la erradicación de: Visón americano (Mustela vison Schreber), rata almizclera (Ondatra zibethicus), coipú (Myocastor coypus) ardilla gris (Sciurus carolinensis), malvasía canela (Oxyura jamaicensis), ciervo sica (Cervus nippon), mapache (Procyon lotor), perro mapache (Nyctereutes
} 
Estrategia Europea de EEI; la Recomendación n ${ }^{0}$ 153, de 2 de diciembre de 2011, sobre la Carta de Conservación y Uso Sostenible de la Biodiversidad en las islas de Europa ${ }^{16}$, así como la Recomendación $\mathrm{n}^{\mathrm{0}}$ 154, de la misma fecha, sobre el Código de Conducta sobre Animales Domésticos y de Compañía y Especies Exóticas Invasoras ${ }^{17}$, que incluye las especies de acuariofilia y terrarios, así como el empleo de cebos vivos para la pesca recreativa y alimentos vivos. El Consejo de Europa también se ha ocupado del Código de Conducta Europeo sobre Parques Zoológicos, Acuarios y Especies Exóticas Invasoras, vectores de introducción y expansión de especies invasoras ${ }^{18}$. Sobre la actividad de cada Estado signatario, puede consultarse el Informe del Grupo de Expertos sobre Especies Invasoras del Consejo de Europa, en el que se detallan las actuaciones de gran parte llevadas a cabo siguiendo este Convenio y el $\mathrm{CDB}^{19}$.

Tanto el CDB como el Convenio de Berna y el Convenio de Bonn son las normas principales que recogen las previsiones más amplias sobre las especies invasoras. Pasamos ahora a revisar otros instrumentos del Derecho internacional que de modo más sectorial regulan las $\mathrm{EEI}^{20}$.

Dado que una de las principales de las vías de expansión de las EEI es el comercio internacional tenemos que acudir a las normas sobre el mismo. De esta manera, en relación con el comercio de las especies, la Convención sobre el Comercio Internacional

procyonoides), castor americano (Castor canadensis), tortuga de Florida (Trachemys scripta) y rana toro (Rana catesbeiana).

${ }^{16}$ Recommendation No. 153 (2011) of the Standing Committee, adopted on the $2^{\text {nd }}$ of December 2011, on the Charter on the Conservation and Sustainable Use of Biological Diversity on European Islands. En este texto se subraya la importancia de evitar su introducción y su expansión, por lo que por tanto llama a redoblar los esfuerzos para conseguir su detección y erradicación. Los efectos en hábitats insulares se multiplican debido al carácter aislado de toda isla, donde la evolución ha seguido caminos diferentes de los continentes.

${ }^{17}$ Recommendation No. 154 (2011) of the Standing Committee, adopted on the $2^{\text {nd }}$ of December 2011, on the European Code of Conduct on Pets and Invasive Alien Species.

${ }^{18}$ European Code of Conduct on Zoological Gardens, Aquaria and Invasive Alien Species, cuyo borrador de 3 de octubre de 2011 cuenta con la reseña T-PVS/Inf (2011)26.

19 T-PVS (2011)6, de 18 a 20 de mayo de 2011. Existen otras Recomendaciones y textos sobre especies invasoras en relación con diversas materias como la de caza (T-PVS Inf (2011) 19E), los espacios protegidos (T-PVS Inf (2011) 06E), las plantaciones para biocombustibles (T-PVs Inf (2009) 06E) y el cambio climático (Rec 20098142 E).

${ }^{20}$ Otros acuerdos de ámbito regional que recogen medidas contra las invasiones biológicas son el Convenio para la Protección de los Alpes de 1991, el Convenio para la Pesca en el Danubio de 1958, ya citado, la Convención OSPAR de 1998, la Convención para la Protección del Medio Marino del Báltico de 1992 o el Acuerdo para la conservación de las aves acuáticas migradoras de África y Eurasia. Vid. BARREIRA, A., et al., Medio ambiente y Derecho Internacional. Una guía práctica, Caja Madrid, Madrid, 2007. 
de Especies Amenazadas de Flora y Fauna Silvestres (CITES), de 3 de marzo de 1973, el art. XIV.1 permite el que las Partes puedan adoptar medidas internas más estrictas respecto de las condiciones de comercio, captura, posesión o transporte de especímenes de especies incluidas en los Apéndices I, II y III, o prohibirlos enteramente, así como las medidas internas que restrinjan o prohíban el comercio, la captura, la posesión o el transporte de especies no incluidas en los Apéndices I, II o III. A su vez, el apartado $2^{\circ}$ de este art. XIV indica que las disposiciones de esta Convención no afectarán en modo alguno las disposiciones de cualquier medida interna $\mathrm{u}$ obligaciones de las Partes derivadas de un tratado, convención o acuerdo internacional referentes a otros aspectos del comercio, la captura, la posesión o el transporte de especímenes que está en vigor o entre en vigor con posterioridad para cualquiera de las Partes, incluidas las medidas relativas a la aduana, salud pública o a las cuarentenas vegetales o animales. Es decir, la CITES permite a los Estados que son parte del mismo la restricción o incluso anulación de la entrada en su territorio de especies que pueden ser consideradas EEI, cuestión que ha informado la legislación nacional y comunitaria en variadas ocasiones ${ }^{21}$.

En esta misma línea, recordamos que la $14^{\mathrm{a}}$ Conferencia de las Partes de la CITES les recomendaba que tuvieran en cuenta los problemas de las especies invasoras al redactar leyes y reglamentos nacionales sobre el comercio de especímenes vivos de animales o plantas; que consultaran con la Autoridad administrativa del país importador propuesto, siempre que fuera posible, al examinar las exportaciones de especies potencialmente invasoras, a fin de determinar si existen medidas internas para reglamentar esas importaciones; y que examinasen las posibilidades de sinergia entre la CITES y el CDB, y la oportunidad de una cooperación y colaboración adecuadas entre ambas Convenciones sobre la cuestión de la introducción de especies exóticas potencialmente

${ }^{21}$ Como la prohibición desde 1997 de la importación de la tortuga de Florida (Trachemys scripta elegans), la rana toro (Lithobates catesbeianus), la tortuga pintada (Chrysemys picta) y la malvasía canela (Oxyura jamaicensis). 
invasoras $^{22}$. De hecho, la colaboración entre las secretarías de ambos convenios es fluida y de gran importancia práctica ${ }^{23}$.

En relación con el comercio internacional, no podemos dejar de tener en cuenta el Acuerdo de Medidas Sanitarias y Fitosanitarias (MSF) de la Organización Mundial de Comercio $^{24}$, aprobado con el fin de evitar la aplicación de medidas proteccionistas con la excusa de situaciones de alerta sanitaria, con el fin general de proteger, bajo estrictos criterios científicos, la salud y la vida de los animales o para preservar los vegetales en el territorio del Miembro de los riesgos resultantes de la entrada, radicación o propagación de plagas, enfermedades y organismos patógenos o portadores de enfermedades, que cuentan con especiales vectores en las especies invasoras. El MSF se relaciona de modo estrecho con la Comisión del Codex Alimentarius, la Oficina Internacional de Epizootias y la Convención Internacional de Protección Fitosanitaria. En la actualidad, con el fin de favorecer el comercio se reconoce la presión para adoptar medidas sanitarias y fitosanitarias "aceptables" en vez de exigir requisitos que impongan riesgos mínimos en el tráfico de especies invasoras ${ }^{25}$.

Otro instrumento internacional de gran importancia, dado que la mayor parte de las invasiones biológicas tienen como protagonistas los hábitats y especies acuáticas, gracias sobre todo al tráfico marítimo ${ }^{26}$, es la Convención internacional para el control y gestión del agua de lastre y los sedimentos de los buques, aprobada en el ámbito de la

\footnotetext{
${ }^{22}$ La CITES ha publicado este documento: "Guías para la prevención de pérdidas de diversidad biológica ocasionadas por exóticas invasoras", de febrero de 2000 y aprobadas en la 51 a Sesión del Consejo. Este documento se basa en el principio de prevención, el de acción rápida y en la consideración ante casos de duda de que toda introducción es dañina salvo prueba en contrario. Se basa también los principios de erradicación y control, sin que la falta de evidencia científica y económica sobre las consecuencias de una invasión biológica se emplee como una razón para posponer la erradicación, la contención u otras medidas de control.

${ }^{23}$ Cuestión que se plasma en sus documentos de trabajo: Decisión 10.76 de 2004 o en la Resolución 13.10 de la $14^{\mathrm{a}}$ Conferencia de las Partes de junio de 2007, por citar solamente un par de ejemplos.

${ }^{24}$ Sobre el comercio internacional de EEI, recomendamos la consulta de esta obra: BURGIEL, S., FOOTE, G., ORELLANA, M. y PERRAULT, A., Invasive alien species and trade: integrating prevention measures and international trade rules, The Center for International Environmental Law and Defenders of Wildlife, Washington, DC, 2006.

${ }^{25}$ Vid. el documento del CITES, Global strategy on invasive alien species, Washinton DC, 2000, con la reseña Inf. AC.16.12.

${ }^{26}$ Resaltemos simplemente estas especies, de las miles que se transportan día a día en las flotas mercantes: el mejillón cebra (Dreissena polymorpha), la almeja asiática (Corbicula fluminea), el camarón oriental (Palaemon macrodactylus), el mejillón dorado (Limnoperna fortunei) y el cangrejo chino (Ericheir sinensis). El agua de lastre transportada anualmente oscila entre los 3 mil y 5 mil millones de toneladas, según la OMI. Recomendamos la consulta de sus Guías Técnicas, disponibles en http://globallast.imo.org, y que incluyen cuestiones de diseño de los buques y de gestión de estas aguas.
} 
Organización Marítima Internacional (OMI) el 13 de febrero de 2004. Se prevén sistemas de inspección y certificados, así como el diseño adecuado de los tanques de lastre y la construcción y mantenimiento de instalaciones portuarias de recepción, con el fin de "prevenir, reducir al mínimo y, en último término, eliminar la transferencia de organismos acuáticos perjudiciales y agentes patógenos mediante el control y la gestión del agua de lastre y los sedimentos de los buques" ${ }^{27}$, todo ello como desarrollo del art. 196.1 de la Convención de las Naciones Unidas sobre el Derecho del Mar, de 16 de diciembre de 1982, que estipula que "los Estados tomarán todas las medidas necesarias para prevenir, reducir y controlar la contaminación del medio marino causada por la utilización de tecnologías bajo su jurisdicción o control, o la introducción intencional o accidental en un sector determinado del medio marino de especies extrañas o nuevas que puedan causar en él cambios considerables y perjudiciales".

Sin salir del hábitat acuático, hemos de referirnos a la Convención de las Naciones Unidas sobre el Derecho de los usos de los cursos de agua internacionales para fines distintos de la navegación, de 21 de mayo de 1997, cuyo art. 22 habla de la “introducción de especies extrañas o nuevas" y establece que los Estados del curso de agua tomarán todas las medidas necesarias para impedir la introducción en un curso de agua internacional de especies extrañas o nuevas que puedan tener efectos nocivos para el ecosistema del curso de agua de resultas de los cuales otros Estados del curso de agua sufran daños sensibles ${ }^{28}$. Lamentablemente, esta Convención no ha entrado en vigor todavía.

Para terminar con la revisión de las fuentes del Derecho internacional sobre especies invasoras, es hora de hablar de la Convención Ramsar, uno de los instrumentos jurídicos capitales del Derecho de la Biodiversidad, dado el especial énfasis dado a la protección de los humedales. Con antecedentes en la Resolución VII.14 de 1999, la Resolución VIII.18, adoptada en 2002, insta a realizar evaluaciones de riesgo de las especies exóticas que pueden suponer una amenaza para las características ecológicas de los humedales, así como a identificar la presencia de EEI en los sitios Ramsar y otros humedales, las amenazas que les suponen, con inclusión del riesgo de que especies que

\footnotetext{
${ }^{27}$ Art. 2 de la Convención.

${ }^{28}$ Pensemos como ejemplo en las cuencas ibéricas y en los efectos de las sueltas con fines de pesca recreativa de alburno (Alburnus alburnus), lucioperca (Sander lucioperca), siluro (Silurus glanis) o "black-bass" (Micropterus salmoides) que van colonizando aguas abajo los ríos compartidos. Como podrá apreciarse, la reciente normativa española de EEI va en esta dirección de la toma de las medidas necesarias.
} 
aún no están presentes en dichos sitios puedan invadirlos, o las acciones que están en curso o que están previstas para su prevención, erradicación y control ${ }^{29}$. Por otra parte, desde el punto de vista del principio de precaución, se insta también a que, en el desarrollo y aplicación de sus estrategias nacionales y en sus respuestas ante las especies exóticas invasoras, reconozcan que las invasiones terrestres de especies exóticas pueden amenazar y afectar a las características ecológicas de los humedales, con inclusión de descensos de las capas freáticas y alteraciones de las pautas de flujo del agua, y a que velen por la adopción de medidas adecuadas para prevenir o controlar dichas invasiones. Los trasvases entre cuencas también merecen la atención del Convenio Ramsar, por lo que se solicita que antes de trasvasar aguas entre cuencas fluviales, las Partes examinen meticulosamente los impactos ambientales potenciales debido a las especies invasoras ${ }^{30}$.

\section{LA PROTECCIÓN DE LA BIODIVERSIDAD AUTÓCTONA FRENTE A LAS ESPECIES EXÓTICAS INVASORAS EN LA UE: SU EVOLUCIÓN LEGAL Y JURISPRUDENCIAL BAJO EL PRINCIPIO DE PRECAUCIÓN}

El Derecho de la Biodiversidad promulgado por la Unión Europea refleja sin duda alguna uno de los modelos más avanzados a nivel mundial de la protección jurídica de la vida en la Tierra ${ }^{31}$, por ello, no es extraño que la cuestión de las EEI haya recibido

\footnotetext{
${ }^{29}$ Ya hay experiencias de EEI en humedales españoles como La Albufera de Valencia y Doñana, en concreto de miles de ejemplares de la tortuga de Florida (Trachemys scripta elegans), la tortuga de vientre rojo (Pseudemys nelsoni) y la falsa tortuga mapa (Graptemys pseudographica). En otros humedales andaluces se han ejecutado en la primera década de este siglo trabajos de erradicación de black-bass, carpa (Cyprinius carpio), carpín dorado (Carassius auratus), perca-sol (Lepomis gibbosus) y chanchito (Australoheros facetas), en el marco del Programa Andaluz para el Control de Especies Exóticas Invasoras. En cuanto al reino vegetal, son dignos de cita a nivel mundial como amenazas ciertas a muy variados humedales la lenteja de agua (Lemna spp.), la caña común (Arundo donax), la hierba de la Pampa (Cortaderia selloana), el polígono japonés (Fallopia japonica) y el camalote (Eichornia crassipes), de los que sobresale el trabajo de erradicación de esta última planta en el Guadiana.

${ }^{30}$ Un ejemplo notorio lo representa la amenaza de expansión del mejillón cebra desde el Ebro. El WWF explica a su vez que "el trasvase Tajo-Segura es el responsable de la entrada del pez rojo (Carassius auratus), del gobio (Gobio gobio) y de la boga del Tajo (Chondrostoma polylepis) en la cuenca del Júcar, y de la bermejuela (Rutilus arcasii) en la cuenca del Guadiana. Las primeras consecuencias ya se están conociendo, pues la boga del Tajo se ha hibridado con la loina del Júcar (Chondrostoma arrigonis) con lo que esta especie se encuentra en serio riesgo de desaparición. Este problema es particularmente preocupante en la Península Ibérica, pues la mayoría de especies y subespecies piscícolas son endémicas de las distintas cuencas". Vid. WWF, El trasvase Tajo-Segura. Lecciones del pasado, Madrid, 2003.

${ }^{31}$ Es indispensable la consulta de esta obra: GARCÍA URETA, A., Derecho europeo de la biodiversidad. Aves silvestres, hábitats y especies de flora y fauna, Iustel, Madrid, 2010.
} 
recientemente una considerable atención en las instituciones comunitarias ${ }^{32}$. Así, en 2008 se publicó la Comunicación de la Comisión "Hacia una estrategia de la UE sobre especies invasoras" ${ }^{33}$, en la cual se exponen el grave daño que suponen para la biodiversidad, la economía ${ }^{34}$ y la salud, con una relación de algunos ejemplos de importancia, al mismo tiempo que reconoce que "si la colonia local de la especie invasora no se detecta y erradica con rapidez, entonces se crea una población sostenible a escala local que se dispersará en nuevos territorios. Es evidente que si se han constituido varias poblaciones locales a partir de una población original, el proceso de dispersión se acelerará ... Al final, tras un período de años o décadas, una especie puede haber colonizado varios países y, por consiguiente, será casi imposible acabar con ella"35. Teniendo en cuenta el enfoque preventivo se publicaron diversas normas que proscriben esta práctica, como el pionero Reglamento (CE) nº 2551/97, de la Comisión, de 15 de diciembre, por el que se suspende la introducción en la Comunidad de especímenes de algunas especies de fauna y flora silvestres, hasta el más reciente Reglamento de Ejecución 828/2011, de la Comisión, de 17 de agosto, por el que se suspende la introducción en la Unión de especímenes de determinadas especies de fauna y flora silvestres, cuyos anexos han aumentado progresivamente ${ }^{36}$.

\footnotetext{
32 Puede visitarse la página especializada de la Comisión: http://ec.europa.eu/environment/nature/invasivealien

${ }^{33}$ COMISIÓN EUROPEA, Hacia una estrategia de la UE sobre especies invasoras, COM (2008) 0789 final, Bruselas, 2008.
}

${ }^{34}$ Esta Comunicación expone que "en 2008, una primera estimación ha permitido situar los costes anuales ocasionados por las especies invasoras en Europa entre 9.600 millones de euros y 12.700 millones de euros. No hay duda de que los costes se han subestimado, ya que esa cifra se basa en los gastos actuales de erradicación y control de las especies invasoras y en los costes probados del impacto económico. Si se tiene en cuenta que muchos países empiezan ahora a documentar y registrar costes y efectos, el coste económico real será mucho mayor". Vid. SCALERA R., "How much is Europe spending on invasive alien species? "Biological Invasions, núm. 12(1), 2010.

${ }^{35}$ Teniendo en cuenta estas cuestiones, la Comisión recuerda, citamos casi literalmente, que la estrategia adecuada se basa en la adopción de medidas basadas en primer lugar en la prevención, a lo que le sigue la pronta detección y la erradicación, junto con la contención y medidas de control a largo plazo. Este enfoque se aplica a las nuevas introducciones y a la gestión de las especies invasoras establecidas y refleja el consenso científico y político de que, en general, la prevención es preferible desde los puntos de vista económico y ecológico a la adopción de medidas una vez las especies introducidas. No obstante, si ya se ha producido la entrada de una especie invasora, una pronta detección y una erradicación rápida son los medios más rentables, respaldados por sistemas de alerta rápida y de intercambio de información, para impedir su establecimiento y propagación. En caso de que no sea posible la erradicación, deben aplicarse medidas de contención y/o control.

${ }^{36}$ Estas normas tienen por origen el Reglamento (CE) 338/97 del Consejo, relativo a la protección de especies de la fauna y flora silvestres mediante el control de su comercio, modificado recientemente por el Reglamento (UE) $n^{\circ} 101 / 2012$ de la Comisión, de 6 de febrero, de acuerdo con el convenio CITES y sus requisitos de expedición de autorizaciones de importación y exportación, así como ciertas verificaciones, según la especie y el país de origen. 
La estrecha relación comercio-EEI se ha puesto de manifiesto en la jurisprudencia comunitaria. En efecto, la Sentencia del Tribunal Europeo de Justicia (Sala Sexta) de 13 de julio de 1994, Comisión/Alemania, dilucidó si en virtud de los antiguos artículos 30 y 36 del Tratado CEE, la prohibición, en la medida en que no respondieran a objetivos de investigación y de enseñanza, las importaciones de cangrejos de río vivos ${ }^{37}$ de las especies europeas procedentes de los Estados miembros o de países terceros y que se encontrasen en libre práctica en los demás Estados miembros. Además, el Reglamento Federal sobre la Protección de las Especies de 1989 supeditó la importación de todas las especies de cangrejos de río vivos a la obtención de una autorización.

Como se explica en esta sentencia, del recurso de la Comisión se desprende que tanto la contaminación de las aguas como, sobre todo, la peste de los cangrejos de río, cuya propagación se debe a la importación de cangrejos americanos infectados, habían llevado a la práctica extinción de los cangrejos de río autóctonos. Como estos no resultaban suficientes, Alemania importaba desde hacía muchos años varias decenas de toneladas de cangrejos de río vivos cada año bajo autorización ${ }^{38}$. La Comisión mantuvo esencialmente que la normativa alemana resultaba incompatible con los antiguos artículos 30 y 36 del Tratado CEE, por cuanto obstaculizaba las importaciones de cangrejos de río vivos originarios de otros Estados miembros y porque iba más allá de las exigencias de una protección eficaz de las especies autóctonas. El Gobierno alemán alegó que, en la medida en que se habían concedido a los importadores amplias

\footnotetext{
${ }^{37}$ Ciertas especies de cangrejos europeos se han visto diezmadas hasta casi la extinción por, entre otras plagas, la afanomicosis, enfermedad causada por el hongo Aphanomyces astaci y transmitida por otros crustáceos, con graves consecuencias ambientales y económicas. Este hongo se introdujo en España gracias a unas sueltas clandestinas de cangrejo rojo americano, una de las especies invasoras más dañinas, a principio de los años setenta del siglo XX en las marismas del Guadalquivir; posteriormente se llevaron a cabo innumerables sueltas, a lo que se sumó la llegada de otro portador de este hongo, el cangrejo señal, de la mano de las Administraciones públicas, como "sustituto" del autóctono (Austropotamobius pallipes), un claro ejemplo de consecuencias perniciosas en cadena donde las haya. Vid. ALONSO GUTIÉRREZ, F., "La dispersión de los cangrejos rojo y señal en Castilla-La Mancha: ¿son válidas las medidas de gestión de especies invasoras a nivel geográfico de comunidad autónoma?", Foresta, núm. 47, 2010; del mismo autor: "Austropotamobius pallipes", Ríos con Vida, núm. 81, 2008. PRADILLO, A., "El cangrejo de río autóctono vuelve a los ríos valencianos", Quercus, núm. 312, 2012.

${ }^{38}$ Tales autorizaciones eran válidas únicamente para seis meses y con la obligación de indicar la cantidad exacta importada, el país de origen y la denominación de la especie de que se trate, estando sujetas al cumplimiento de condiciones destinadas a garantizar, entre otras cosas, que los cangrejos de río se entregasen únicamente al comprador final, con exclusión de los mayoristas y de los revendedores, el cual había de adoptar todas las medidas de prevención y de desinfección adecuadas, a impedir que quedasen en libertad los cangrejos de río importados y a garantizar que, antes de verterla, se desinfectara el agua que hubiera servido para conservar a los animales. En caso de inobservancia de estas condiciones, la autorización podía revocarse.
} 
dispensas de la prohibición controvertida, la normativa impugnada ni había suprimido toda importación de cangrejos de río ni había convertido el mercado alemán en un compartimento estanco, añadiendo que, en cualquier caso, dicha normativa se justificaba con arreglo al antiguo artículo 36 del Tratado CEE, puesto que la medida impugnada resultaba indispensable para protegerse contra la peste.

A ello respondió el Tribunal con que según la organización común de mercados en el sector de los productos de la pesca ${ }^{39}$, eran plenamente aplicables las medidas contra las restricciones cuantitativas, por lo que una normativa restrictiva de los intercambios intracomunitarios sólo era compatible con el Tratado en la medida en que resultase indispensable para una protección eficaz de la salud y vida de los animales. Por lo tanto, la normativa alemana, que se amparaba también en el CITES, no podía acogerse a la excepción del artículo 36 TCEE cuando tal objetivo pudiese alcanzarse de una manera igualmente eficaz con medidas que tuvieran efectos menos restrictivos para los intercambios intracomunitarios ${ }^{40}$. A todo ello añadimos nosotros que, transcurrido muchos años desde esta decisión en los que los conocimientos científicos ha avanzado sustancialmente y dada la situación actual de práctica extinción de las variedades autóctonas de estos crustáceos, se ha probado científicamente el grave riesgo de liberar cangrejos portadores de la especie, como el cangrejo rojo americano y el señal, cuya mera presencia impide la recuperación de las antiguas poblaciones de cangrejo autóctono $^{41}$.

La atención sobre los efectos perjudiciales de las EEI se ha redoblado en los últimos años, siendo uno de los objetivos de la "Estrategia de la UE sobre biodiversidad hasta el

\footnotetext{
${ }^{39}$ Recogida entonces en el Reglamento 3796/81, de 29 de diciembre de 1981.

40 “Así, en lugar de prohibir pura y simplemente la importación de todas las especies de cangrejos de río vivos, Alemania habría podido limitarse a someter a controles sanitarios las partidas de cangrejos de río procedentes de otros Estados miembros o en libre práctica en la Comunidad y a efectuar únicamente controles por sondeo, en la medida en que dichas partidas estuvieran acompañadas de un certificado sanitario, expedido por las autoridades competentes del Estado miembro de procedencia y que acreditara que el producto de que se tratara no presentaba ningún riesgo para la salud, o bien limitarse a regular la comercialización de los cangrejos de río en su territorio, en particular sometiendo a autorización tan sólo la repoblación de las aguas interiores con especies susceptibles de ser portadoras del agente de la peste y restringiendo la puesta en libertad de los animales así como la repoblación en las zonas donde viven especies autóctonas".

${ }^{41}$ De esto trató una sentencia del Tribunal Constitucional sobre la prohibición de la venta del cangrejo rojo en Castilla y Léon, como veremos más adelante.
} 
2020: Nuestro seguro de vida y capital natural", comunicación de la Comisión ${ }^{42}$ que establece como uno de sus objetivos principales, el quinto, lo siguiente: "Determinar y jerarquizar por orden de prioridad, no más tarde de 2020, las especies exóticas invasoras y sus vías de penetración, controlar o erradicar las especies prioritarias y gestionar las vías de penetración para impedir la irrupción y establecimiento de nuevas especies"43.

En cualquier caso, estos últimos impulsos comunitarios cuentan con importantes precedentes jurídicos, pues ya a finales de los años setenta del siglo XX, la Directiva de Aves 79/409/CEE, de 2 de abril, recogía en su art. 11 que "los Estados miembros velarán por evitar que la eventual introducción de especies de aves que no vivan normalmente en estado salvaje en el territorio europeo de los Estados miembros perjudique a la flora y la fauna locales. Consultarán al respecto a la Comisión”, redacción que continúa bajo la nueva regulación de las aves silvestres de la Directiva 2009/147/CE, de 30 de noviembre. La sentencia del Tribunal Europeo de Justicia (Sala Cuarta), Comisión/Austria, de 12 de julio de 2007, interpretó esta norma en relación con el art. 17.5 de la Ley de la Baja Austria de protección de la Naturaleza, bajo el cual quedaba sometida a autorización plantar y promover flora no autóctona e inadaptada a la zona de que se tratase, así como introducir y promover, en espacios no cerrados, fauna no autóctona. La autorización se denegaría cuando las poblaciones autóctonas adaptadas, las características naturales (genéticas) de las especies de la fauna y flora autóctona o la belleza y las características del paisaje resultasen afectadas de forma duradera. El Tribunal entendió que el art. 11 de la Directiva de Aves se limitaba a imponer a los Estados miembros la obligación específica de velar por que la introducción de especies de aves que no vivieran normalmente en estado silvestre en el territorio europeo de los Estados miembros no perjudicase a la flora y la fauna locales. Por consiguiente, no puede considerarse que dicho artículo constituya una base jurídica que permita eximir de las obligaciones de protección que incumben a los Estados

\footnotetext{
${ }^{42}$ COMISIÓN EUROPEA, Estrategia de la UE sobre biodiversidad hasta el 2020: Nuestro seguro de vida y capital natural, COM (2011) 244 final, Bruselas, 2011. Se abrieron consultas al público hasta abril de 2012 sobre la política y el régimen jurídico comunitario de las EEI.

${ }^{43}$ Para ello se prevé un par de actuaciones prioritarias: Actuación 15: Fortalecer los regímenes fitosanitarios y de sanidad animal de la UE: La Comisión integrará nuevos aspectos relacionados con la biodiversidad en los regímenes fitosanitarios y de sanidad animal no más tarde de 2012. Actuación 16: Crear un instrumento especial relativo a las especies exóticas invasoras: La Comisión colmará las lagunas que existen en la política de lucha contra las especies exóticas invasoras elaborando un instrumento legislativo especial antes de que concluya 2012.
} 
miembros en virtud del artículo 1 de la Directiva" y que se refieren a "todas" las especies de aves que vivan normalmente en estado silvestre en el territorio europeo de los Estados miembros, es decir, en lo que atañe a cada uno de estos Estados, tanto las especies que en ellos son autóctonas como aquellas cuya presencia sólo se da en otros Estados miembros, no sólo las que habitan en Austria. En efecto, añade la sentencia, la importancia de una protección completa y eficaz de las aves silvestres dentro de la UE, cualquiera que sea su lugar de estancia o su espacio de paso, hace incompatible con la Directiva toda legislación nacional que determine la protección de las aves silvestres en función de la fauna nacional.

Por su parte, el art. 22.b) de la Directiva 92/43/CEE, de 21 de mayo, de hábitats naturales y de la flora y fauna silvestres establece que los Estados miembros garantizarán que la introducción intencionada en la naturaleza de una especie que no sea autóctona de su territorio se regule de modo que no perjudique a la fauna y flora silvestres autóctonas ni a sus hábitats naturales en su zona de distribución natural y, si lo consideraren necesario, prohibirán dicha introducción. Sobre esta disposición se ha pronunciado el Tribunal Europeo de Justicia, Sala Cuarta, cuya sentencia de 10 de mayo de 2007 reconoció su incumplimiento por parte de la República de Austria, la cual fue condenada en costas. En concreto, se discutía por la Comisión la adecuación a la Directiva de Hábitats del art. 17.5 de la Ley de Baja Austria relativa a la protección de la Naturaleza, ya comentado. Las alegaciones de la Comisión Europea se basaban en que se hacía depender la concesión de una autorización de introducción de especies no autóctonas de un criterio no previsto por la Directiva, a saber, que el eventual perjuicio no fuese "duradero". Por otra parte, según la Comisión, esta disposición no impedía todos los perjuicios a los hábitats naturales en su área de distribución natural y a la fauna y flora silvestres autóctonas debido a la introducción deliberada de especies no autóctonas. Por el contrario, sin mayor argumentación, Austria entendía que la autorización para introducir en la naturaleza una especie no autóctona o no adaptada a

\footnotetext{
${ }^{44}$ A tenor de su artículo 1, apartado 1, la Directiva de Aves se refiere a la conservación de todas las especies de aves que viven normalmente en estado silvestre en el territorio europeo de los Estados miembros en el que es aplicable el Tratado de la Unión. Tiene por objeto la protección, la administración y la regulación de dichas especies, y regula su explotación. El apartado 2 de dicho artículo establece que la Directiva se aplica a las aves, así como a sus huevos, nidos y hábitats.
} 
las condiciones locales se denegaría siempre que tal intervención perjudicara a la fauna o la flora autóctonas ${ }^{45}$. El Tribunal entendió en fin que Austria permitía la introducción deliberada de especies animales o vegetales no autóctonos a condición de que los hábitats naturales y la fauna y flora silvestres autóctonas no se vieran afectados de forma permanente, lo cual no constituye una adaptación correcta al régimen de protección de la Directiva. En efecto, este régimen exige que cualquier excepción respete los requisitos impuestos en el artículo 22, letra b) de la Directiva, especialmente el de que la autorización sólo pueda concederse si no perjudica a los hábitats naturales, mientras que la expresión "no perjudique" constituye una exigencia de protección desprovista de ambigüedad temporal aludida, que excede de la enunciada por la norma austriaca, de ahí el incumplimiento de la Directiva de Hábitats ${ }^{46}$.

Esta última sentencia es de gran importancia porque los partidarios de las EEI, sobre todo las que son objeto de pesca recreativa, esgrimen la fatua idea de que ciertas especies llevan un determinado número de décadas y que por tanto están "naturalizadas" y han perdido su carácter invasor, algo totalmente falto de rigor científico ${ }^{47}$, lo que constituye sin más una mera ocurrencia que a pesar de todo encuentra cierto eco en algunas Administraciones públicas, las cuales, no olvidemos, han de regirse siempre por el principio de objetividad recogido en el art. 103 de la Constitución. También se predica esta sentencia de las sueltas intensivas periódicas en ciertos cotos de pesca de ejemplares de especies invasoras como la trucha arco-iris ${ }^{48}$ y variedades alóctonas de

${ }^{45}$ Lo que en nuestra opinión es un criterio laxo en demasía y verdaderamente apodíctico, sobre todo cuando se habla de nuevas especies invasoras cuyos efectos se desconocen aún por la Ciencia y que los efectos temporales se ven desde una escala humana y no desde el punto de vista de la escala evolutiva, lo que arrumba también el principio de precaución. CONSEJO GENERAL DEL PODER JUDICIAL, $E l$ principio de precaución y su proyección en el Derecho administrativo español, Madrid, 2005.

${ }^{46}$ Con tenor parecido, vid. la sentencia de la Sala Sexta de 13 de febrero de 2003, sobre una demanda de la Comisión contra el Gran Ducado de Luxemburgo, que fue condenado en costas.

${ }^{47}$ RICHARDSON, DAVID M. et al, "Naturalization and invasión of alien plants: concepts and definitions, Diversity and Distributions, núm. 6, 2000. En este trabajo se examina la identificación entre especie naturalizada y las exóticas e invasoras. En ningún caso ha de entenderse "naturalizada" como sinónimo de inocua.

48 Por su claridad expositiva y la abundante información que ofrece, es imprescindible la consulta detenida de esta obra sobre una de las EEI con mayores efectos ambientales, la trucha arco-iris: HALVERSON, A., An enterily synthetic fish. How rainbow trout beguiled America and overran the World, Yale University Press, New Haven, 2010. Sobre esta especie y las variedades alóctonas de trucha común, vid. BLASCO, J. M ${ }^{\mathrm{a}}$., BRUFAO, P. y RODRÍGUEZ C., Truchas invasoras. Informe sobre la ilegalidad de las sueltas masivas de trucha arco-iris (Oncorhynchus mykiss) y variedades alóctonas de trucha común (Salmo trutta) con fines de pesca deportiva, Ríos con Vida, El Tiemblo, 2010. Una de las enfermedades más importantes difundidas por la cría de esta especie es la conocida como "whirling desease", vid. BARTHOLOMEW, J.L. y RENO, P.W., "The history and dissemination of whirling desease", American Fisheries Society Symposium, núm. 29: 3-24, 2002. 
trucha común, defendidas bajo el argumento de que generalmente no se reproducen o no logran superar un cierto tiempo en los ríos y humedales donde se liberan, práctica que esconde el hecho indubitado de que siempre habrá una determinada cantidad de ejemplares en un hábitat que no les es propio.

También es de interés las normativa zoológica específica desde un punto de vista mercantil, como la Directiva 91/174/CEE del Consejo, de 25 de marzo de 1991, relativa a las normas zootécnicas y genealógicas que regulan la comercialización de animales de raza, por la que se modifican las Directivas 77/504/CEE y 90/425/CEE, interpretada por la Sentencia del Tribunal Europeo de Justicia (Sala Quinta) de 3 de diciembre de 1998, recaída sobre un asunto de liberación de especies exóticas, en relación directa con el art. 8 h), del Convenio sobre la Diversidad Biológica. Esta sentencia tiene su origen en una cuestión prejudicial interpuesta por un tribunal danés acerca de ciertas restricciones impuestas al comercio de abejas de la subespecie Apis mellifera mellifera. Esta cuestión se suscitó en el marco de un proceso penal seguido contra una persona acusada de haber infringido la normativa nacional que prohíbe poseer, en la isla de Læsø, abejas que no pertenezcan a la subespecie conocida como "abeja parda de Læsø”. El tribunal danés preguntaba si una normativa nacional, que prohíba poseer en una isla abejas de una especie cualquiera que no pertenezcan a la subespecie indicada, constituye una medida de efecto equivalente a una restricción cuantitativa ${ }^{49}$ prohibida en principio por los Tratados comunitarios y, si en tal caso, dicha normativa puede estar justificada por razones de protección de la salud y vida de los animales ${ }^{50}$. el Tribunal Europeo

\footnotetext{
${ }^{49}$ Constituye una medida de efecto equivalente a una restricción cuantitativa toda medida que pueda obstaculizar, directa o indirectamente, real o potencialmente el comercio intracomunitario (Sentencia del Tribunal de Justicia de 11 de julio de 1974). La materia se encuentra regulada por los arts. 34 y ss. del Tratado de Funcionamiento de la UE (antiguos arts. 30 y ss. del Tratado de la CE), por los que quedan prohibidas entre los Estados miembros las restricciones cuantitativas a la importación y exportación, así como todas las medidas de efecto equivalente. Sin embargo se permiten las prohibiciones o restricciones justificadas por razones de orden público, moralidad y seguridad públicas, protección de la salud y vida de las personas y animales, preservación de los vegetales, protección del patrimonio artístico, histórico o arqueológico nacional o protección de la propiedad industrial y comercial. Tales prohibiciones o restricciones no deberán constituir un medio de discriminación arbitraria ni una restricción encubierta del comercio entre los Estados miembros.

${ }^{50}$ La norma danesa prohibía con carácter general importar en Læsø y en las islas próximas abejas vivas y sustancias reproductoras de abejas domésticas. A este respecto, la Directiva, entendía por "animal de raza" todo animal de cría incluido en un anexo, cuyos intercambios aún no hayan sido objeto de una normativa comunitaria zootécnica más específica y que esté inscrito o registrado en un registro o en un libro genealógico llevado por una organización o por una asociación de ganaderos reconocida. La Directiva establecía que los Estados habían de velar para que no se prohibiera, restringiese u obstaculizara la comercialización de animales de raza y de sus espermas, óvulos o embriones por razones zootécnicas o genealógicas, así como que se establecieran de manera no discriminatoria los criterios de aprobación y de reconocimiento de las organizaciones o asociaciones de ganaderos, los criterios de
} 
entendió que son aceptables las medidas de preservación de una población animal indígena que presenta características específicas que contribuyan a mantener la diversidad biológica, a lo que se suma el que para dicha conservación de la diversidad biológica es indiferente que el objeto de la protección sea una subespecie aparte, una raza distinta dentro de una especie cualquiera o una mera variedad local, siempre que se trate de poblaciones que tengan características que las distingan de las demás y que, por consiguiente, se las considere dignas de protección, ya sea para protegerlas de un posible peligro de extinción más o menos inminente, ya sea, incluso en el caso de no existir tal riesgo, por un interés científico o de otro tipo en la preservación de la pureza de la población en el lugar de que se trate ${ }^{51}$. En todo caso, debe comprobarse si la normativa nacional es necesaria a la luz de su objetivo de protección y proporcionada en relación con éste, o si se habría podido llegar al mismo resultado con medidas menos rigurosas. El Tribunal consideró probado que era real el riesgo de hibridación y que se produjesen cruces con abejas amarillas debido al carácter recesivo de los genes de la abeja parda. Por lo tanto, la normativa nacional constituyó una medida apropiada en relación con el objetivo perseguido y de acuerdo con el art. 36 del Tratado de Funcionamiento de la Unión Europea debido a razones de protección de la vida y salud de los animales.

Otra decisión de interés sobre EEI y la Directiva de Hábitats es la Sentencia del Tribunal Europeo de Justicia (Sala Tercera) de 4 de diciembre de 2008, Comisión/Países Bajos, acerca de la autorización previa para la siembra de ostras y mejillones de especies autóctonas presentes en Holanda, pero procedentes de otros Estados miembros, por la cual se declaró ilegal esta restricción, pues tal autorización no se exigía respecto de siembras de estas mismas especies en ciertos lugares de Holanda si las larvas provenían de este mismo país, lo que constituía una medida con efecto equivalente a una restricción cuantitativa. Es decir, a sensu contrario, sería conforme a Derecho la restricción a la liberación intencional de especies alóctonas aplicada tanto a actividades llevadas a cabo

inscripción en los libros genealógicos, los criterios de admisión a la reproducción de animales de raza y a la utilización de sus espermas, óvulos y embriones, así como el certificado exigible para su comercialización.

51 El Tribunal emplea el argumento de que la conservación de la diversidad biológica mediante la creación de zonas en las que una población goza de especial protección, método reconocido por el Convenio de Biodiversidad de 1992, especialmente en la letra a) de su artículo 8, ya está prevista en el Derecho comunitario, en particular, las zonas de protección especial previstas en la Directiva de Aves Silvestres o las zonas especiales de conservación previstas en la Directiva de Hábitats. 
por nacionales del mismo país que impone la restricción como a los nacionales de otros Estados miembros.

Sobre el comercio de la fauna íctica, contamos asimismo con el Reglamento (CE) 708/2007 del Consejo, de 11 de junio de 2007, sobre el uso de las especies exóticas y las especies localmente ausentes en la acuicultura ${ }^{52}$, en virtud del cual se pueden aprobar excepciones a la libre circulación de mercancías cuando pueda afectar a la vida de los animales, cuestión de importancia a la hora de valorar el contagio de enfermedades y plagas, nada infrecuentes en la acuicultura y sobre lo cual España no es ajena $^{53}$. Acerca de las cuestiones sanitarias en sentido estricto, es de aplicación la Directiva 2006/88/CE, del Consejo, de 24 de octubre de 2006, relativa a los requisitos zoosanitarios de los animales y de los productos de la acuicultura, y a la prevención y el control de determinadas enfermedades de los animales acuáticos ${ }^{54}$, que recoge disposiciones sobre los animales destinados a liberación y repoblación.

En cuanto a las especies vegetales, la Directiva 2000/29/CE del Consejo de 8 de mayo de 2000 relativa a las medidas de protección contra la introducción en la Comunidad de organismos nocivos para los vegetales o productos vegetales y contra su propagación en el interior de la Comunidad, reformada en numerosas ocasiones, ordena que se prohíba la importación de determinados organismos nocivos, que se condiciones la entrada de vegetales y productos vegetales bajo ciertos requisitos y con una determinada

\footnotetext{
${ }^{52}$ Modificado por Reglamento (UE) n ${ }^{\circ} 304 / 2011$ del Parlamento Europeo y del Consejo, de 9 de marzo de 2011, especialmente por lo que respecta a las instalaciones acuícolas cerradas.

${ }^{53}$ Para ello es de gran importancia el concepto de "instalación acuícola cerrada", que comprende una instalación situada en tierra donde la acuicultura se lleva a cabo en un medio acuático con recirculación del agua y cuyos vertidos no conectan de ningún modo con aguas abiertas antes de ser tamizados y filtrados o percolados y tratados para impedir la liberación de residuos sólidos al entorno acuático y que escapen de la instalación especies de acuicultura y especies no objetivo capaces de sobrevivir y posteriormente reproducirse; además se exige que se impida las pérdidas de especímenes criados o de especies no objetivo y otro material biológico, incluidos los agentes patógenos, debido a factores como predadores, como aves, e inundaciones, ante las cuales debe establecerse una distancia de seguridad entre la instalación y las aguas abiertas, tras una evaluación apropiada realizada por las autoridades competentes. También han de impedir, de manera razonable, las pérdidas de especímenes criados o de especies no objetivo y otro material biológico, incluidos los agentes patógenos, debido a robo o vandalismo, y garantizar la eliminación adecuada de los organismos muertos.

${ }^{54}$ Vid. la Directiva 2008/53/CE de la Comisión, de 30 de abril de 2008 , por la que se modifica el anexo IV de aquella Directiva respecto de la viremia primaveral de la carpa.
} 
procedencia, de acuerdo con un sistema de prolijos anexos, amparándose determinadas actuaciones de emergencia ${ }^{55}$.

Dado que las EEI medran especialmente en los ecosistemas acuáticos, hemos de acudir a la Directiva 2000/60/CE, Marco del Agua (DMA), cuyo fin para las aguas superficiales es la consecución del "buen estado ecológico" en el año 2015 (art. 4), lo que incluye, como es obvio, la calidad biológica ${ }^{56}$. A ello se suma que, ciñéndonos al caso de la fauna íctica en ríos, a la hora de calificar una masa de aguas superficial como en "muy buen estado ecológico", "buen estado" o "estado aceptable" exige estudiar la “composición y abundancia de especies", lo que nos recuerda el caso generalizado de que en gran parte de nuestras cuencas las poblaciones autóctonas estén en franca regresión debido precisamente a la presencia de especies exóticas objeto de la pesca recreativa, la acuicultura y la acuarofilia. La propia Comisión Europea reconoce las EEI como una de las presiones a tener en cuenta en el proceso de la correcta transposición de la $\mathrm{DMA}^{57}$.

Desde el punto de vista ecosistémico del Derecho de la UE, el ciclo hidrológico de la DMA con las aguas costeras enlaza con la protección de los ecosistemas marinos ${ }^{58}$, regulados de modo principal por la Directiva Marco 2008/56/CE, de 17 de junio, sobre la Estrategia Marina (DMEM), cuyo objetivo primordial es la consecución del "buen estado medioambiental" (art.1) de estos hábitats para el año 2021, en cuyo caso "las especies y los hábitats marinos están protegidos, se previene la pérdida de la biodiversidad inducida por el hombre y los diversos componentes biológicos funcionan

\footnotetext{
${ }^{55}$ En estrecha relación con lo anterior, la Organización Europea y Mediterránea para la Protección de las Plantas (OEPP) gestiona un sistema de notificación de organismos nocivos y mantiene listas de especies exóticas invasoras respecto a las cuales se aconseja adoptar una legislación nacional que impida nuevas introducciones y la propagación de, en particular, especies vegetales exóticas invasoras. Recomendamos el estudio del informe: EPPO, Code of conduct on horticulture and invasive alien plants: proceedings of EPPO/Council of Europe Workshop, Oslo, 2009.

${ }^{56}$ Cuyos indicadores se recogen en el anexo $\mathrm{V}$ de la esta norma, de los cuales destacan para los ríos, lagos, aguas costeras, aguas de transición: composición y abundancia de la flora acuática y de la fauna bentónica de invertebrados; composición, abundancia y estructura de edades de la fauna íctica.

57 COMISIÓN EUROPEA, Common Implementation Strategy for the Water Framework Directive (2000/60/EC). Guidance document $n^{\circ}$ 3. Analysis of pressures and impacts, Luxemburgo, 2003, en especial la p. 74 y ss.

${ }^{58}$ Como ejemplo, los escapes de ejemplares de las piscifactorías de agua dulce y las establecidas en humedales costeros afectan sin duda tanto a los ríos en sus tramos altos y medios como a los tramos bajos y las aguas costeras y de transición, sobre todo si se crían especies exóticas que completan su ciclo vital entre el mar y los ríos, ya sean anádromas o catádromas, o sean capaces de resistir diferentes grados de salinidad.
} 
de manera equilibrada" ${ }^{, 59}$. Como criterio científico y jurídico a la hora de valorar dicho buen estado medioambiental, el anexo I de la DMEM, sobre sus "descriptores cualitativos", recoge "las especies alóctonas introducidas por la actividad humana se encuentran presentes en niveles que no afectan de forma adversa a los ecosistemas", mientras que el anexo III, sobre las listas indicativas de características, presiones e impactos incluye la "relación detallada de la presencia temporal, abundancia y distribución espacial de las especies alóctonas o exóticas o, en su caso, de formas genéticamente distintas de las especies nativas, presentes en la región o subregión marina", que también las califica como "perturbación biológica" en el cuadro 2 de este mismo anexo.

Dado que el hilo conductor de la respuesta jurídica ante las EEI son los riesgos y daños ambientales, hemos de acudir a la Directiva 2004/35/CE, de 21 de abril, sobre responsabilidad medioambiental en relación con la prevención y reparación de daños medioambientales (DRMA) ${ }^{60}$. Por "daño medioambiental" ${ }^{61}$ se entienden, entre otras cuestiones, "los daños a las especies y hábitats naturales protegidos, es decir, cualquier daño que produzca efectos adversos significativos en la posibilidad de alcanzar o de mantener el estado favorable de conservación de dichos hábitats o especies", según los criterios de la Directiva de Aves Silvestres y la Directiva de Hábitats, así como "los daños a las aguas, es decir, cualquier daño que produzca efectos adversos significativos en el estado ecológico, químico o cuantitativo, o en el potencial ecológico" definidos en

\footnotetext{
${ }^{59}$ Vid. arts. 1, 3 y 9 de la DMEM.

${ }^{60}$ Esta DRMA ha de convertirse en un verdadero motor de eficiencia y de cumplimiento de la legalidad sectorial, sobre todo teniendo en cuenta que es compatible con el régimen sancionador, penal o administrativo, y con el de responsabilidad civil de cada Estado miembro. JORDANO, J., et al., Estudios sobre la Directiva 2004/35/CE de responsabilidad por daños ambientales y su incidencia en el ordenamiento español, Aranzadi, Cizur Menor, 2005.
}

61 Art. 2.1 de la DRMA. El anexo I de la DRMA recoge "el carácter significativo del daño" que "produzca efectos adversos en la posibilidad de alcanzar o de mantener el estado favorable de conservación de hábitats o especies se evaluará en relación con el estado de conservación que tuviera al producirse el daño, con las prestaciones ofrecidas por las posibilidades recreativas que generan y con su capacidad de regeneración natural. Los cambios adversos significativos en el estado básico deberían determinarse mediante datos mensurables como: el número de individuos, su densidad o la extensión de la zona de presencia; el papel de los individuos concretos o de la zona dañada en relación con la especie o la conservación del hábitat, la rareza de la especie o del hábitat (evaluada en el plano local, regional y superior, incluido el plano comunitario); la capacidad de propagación de la especie (según la dinámica específica de la especie o población de que se trate), su viabilidad o la capacidad de regeneración natural del hábitat (según la dinámica específica de sus especies características o de sus poblaciones); la capacidad de la especie o del hábitat, después de haber sufrido los daños, de recuperar en breve plazo, sin más intervención que el incremento de las medidas de protección, un estado que, tan sólo en virtud de la dinámica de la especie o del hábitat, dé lugar a un estado equivalente o superior al básico". Queda fuera de toda duda que las EEI incluidas en las llamadas "listas negras" ocasionan perjuicios de esta índole. 
la DMA, sin perjuicio de que otras normas comunitarias establezcan criterios más rigurosos de exigencia de responsabilidad ${ }^{62}$. Los perjuicios causados por las EEI encuentran acogida en esta Directiva ya que el art. 3.1 b) expresamente dice que se aplicará “a los daños causados a las especies y hábitats naturales protegidos por actividades profesionales distintas de las enumeradas en el Anexo III y a cualquier amenaza inminente de tales daños debido a alguna de esas actividades, siempre que haya habido culpa o negligencia por parte del operador". Es decir, aunque el régimen objetivo de responsabilidad no se encuentre recogido por la DRMA cuando hablamos estrictamente de EEI, sí que se aplica cuando se produzcan daños o amenazas inminentes ${ }^{63}$ resultado de la imprudencia, como por ejemplo cuando una piscifactoría contenga ejemplares de especies exóticas e incumpla los requisitos de las instalaciones cerradas de acuicultura o cuando sus actividades se realicen sin las licencias administrativas urbanísticas, de aguas e industriales exigibles, o se emplacen en zonas inundables, que fatalmente se inundarán, o cuando sean foco de enfermedades, situaciones que no son tan infrecuentes como pudiera pensarse. A ello habrá que añadir el debido proyecto de restauración ambiental ${ }^{64}$. En cambio, el régimen de responsabilidad objetiva del anexo III se aplicaría a estas actividades de acuicultura de EEI, como a las de especies autóctonas, por lo que respecta de los vertidos a las aguas continentales, el represamiento y captación de agua sujetos a autorización, o a la liberación, transporte in situ y almacenamiento de biocidas y sustancias peligrosas.

La Comisión financia actuaciones para revertir los efectos de las EEI. En concreto, el Programa LIFE concede desde hace tiempo ayudas a proyectos que se ocupan del control y erradicación de especies invasoras ${ }^{65}$. El Sexto Programa Marco de

\footnotetext{
${ }^{62}$ Art. 3.2.

${ }^{63} \mathrm{La}$ "amenaza inminente de daños" se define en el art. 2 como la "probabilidad suficiente de que se produzcan daños medioambientales en un futuro próximo".

${ }^{64}$ Anexo II de la DRMA.

${ }^{65}$ A título ilustrativo, entre 1992 y 2002, se financiaron más de 100 proyectos (con un coste total de 27 millones de euros), y entre 2003 y 2006, 80 proyectos (con un coste total de 17 millones de euros). Ha financiado también un programa de erradicación de la perca negra americana en el Lago de Bañolas (Gerona). De acuerdo con la Asociación Española de Blackbass, en su Memoria de Actividades de 2010: "Durante todo este año hemos negociado con la Dirección General de Medio Natural de Cataluña la coordinación de un traslado de black-bass provenientes de las acciones de descaste de la Oficina Técnica LIFE del Consorci de l'Estany de Banyoles. Las negociaciones llegaron finalmente a la consecución de una autorización de traslado del Departamento responsable de Medio Natural para AEBass y la FCPEIC que se ejecutó el 22 de octubre de 2010. La jornada de traslado concluyó con una denuncia entre departamentos de la misma DGMA, que provocó la desautorización de la suelta de los ejemplares a pie de embalse, tras una semana de trabajo de captura y retención, movilizar un camión cisterna de la Generalitat y trasladar los ejemplares desde Banyoles hasta las inmediaciones del embalse de Santa Ana".
} 
Investigación financió dos proyectos relacionados con las especies invasoras: $\operatorname{ALARM}^{66} \mathrm{y} \mathrm{DAISIE}^{67}$, el cual publicó el primero inventario paneuropeo de especies exóticas invasoras ${ }^{68}$. Recomendamos asimismo el estudio de un importante documento de la Comisión Europea ${ }^{69}$, sobre el régimen jurídico y las políticas de gestión de EEI en todos los países de la UE y en Australia, Canadá, Estados Unidos ${ }^{70}$ y Nueva Zelanda Este estudio se basa en la definición de lo que es una EEI, las medidas de prevención, alerta temprana ${ }^{71}$, los métodos de control y restauración ecológica, así como en la financiación, formación, educación del público, cooperación internacional y análisis coste-beneficio ${ }^{72}$ de las medidas a adoptar, un nuevo campo que sirve para fortalecer las relaciones y la cooperación entre los países miembros ${ }^{73}$, cuestiones que limitan en grado sumo la discrecionalidad administrativa

${ }^{66}$ Proyecto ALARM (Assessing Large-scale Risks for Biodiversity with tested Methods) sobre la evaluación con métodos probados de riesgos a gran escala para la biodiversidad: www.alarmproject.net.

${ }^{67}$ Proyecto DAISIE (Delivering Alien Invasive Species Inventories for Europe) sobre inventarios de especies exóticas invasoras en Europa: www.europe-aliens.org.

${ }^{68}$ Asimismo, el proyecto SAIS (South Atlantic Invasive Species Project), de 2006 a 2009, tuvo por objeto aumentar la capacidad regional para reducir el impacto de las especies invasoras en los territorios británicos de ultramar en el Atlántico Sur.

${ }^{69}$ COMISIÓN EUROPEA, A comparative assessment of existing policies on invasive species in the EU Member States and in selected OECD countries, Bruselas, 2011.

70 Acerca de los EE.UU., recomendamos también la consulta de: ENVIRONMENTAL LAW INSTITUTE, Invasive species control: a comprehensive model state law, Washington DC, 2004. JENKINS, P. T., GENOVESE, K. y RUFFLER, H., Broken screens: The regulation of live animal imports in the United States, Defenders of Wildlife, Washington DC, 2007.

${ }^{71}$ GENOVESI P., SCALERA R., BRUNEL, S., SOLARZ W. y ROY D., Towards an information and early warning system for invasive alien species (IAS) threatening biodiversity in Europe, European Environment Agency, Tech. report 5/2010, Copenhague, 2010.

72 PERRINGS, C. MOONEY, H. y Williamson, M., (eds.), Bioinvasions and globalization: Ecology, Economics, Management, and Policy. Oxford University Press, Oxford, 2010. PERRINGS C., WILLIAMSON M. y DALMAZZONE S. (eds.), The Economics of biological invasions, Edward Elgar, Cheltenham, 2000.

${ }^{73}$ HULME, P. E., PYSEK, P., NENTWIG, W. y VILA, M., "Will threat of biological invasions unite the European Union?”, Science, núm. 4-5, 2010. Desde un punto de vista de análisis de las alternativas planteadas ante qué hacer con las EEI, empleando criterios de análisis económico principalmente, vid. COMISIÓN EUROPEA e INSTITUT FOR EUROPEAN ENVIRONMENTAL POLICY, Assessment to support continued development of the EU Strategy to combat invasive alien species, Bruselas, 2010, en el que frente a las alternativas conocidas como "business as usual", maximizar las medidas voluntarias o reformar puntualmente la normativa comunitaria existente, fundamenta la aprobación de una futura directiva sobre la materia de acuerdo con los siguientes argumentos y en relación con un Reglamento de la UE que regule las importaciones y exportaciones de EEI: "This would provide a flexible framework with minimum standards based on precaution and an invasive alien species (IAS) policy proofing tool to ensure coherence with upcoming instruments and emerging pathways". Por otra parte, es digno de resaltar por su importancia el criterio recogido en el punto 5.1.4 de este informe, sobre la primacía de la no liberación de EEI: "No alien species is intentionally released into the natural environment unless it is possible to exclude or minimise risk of causing impacts to EU biodiversity and ecosystem services". A ello se sigue el siguiente criterio en contra de la suelta de EEI: "The clearest conceptual approach under the Strategy would be to establish a general presumption against the intentional introduction of alien 
a la hora de valorar cuándo nos encontramos ante una EEI y qué respuesta debe darse, y, por tanto, toda norma o acto administrativo que permitiera la suelta de EEI sería contrario a Derecho. Como la mejor doctrina jurídica ha afirmado de modo ilustrativo: "No puede quedar al arbitrio de la Administración discernir si un hecho se ha cumplido o no se ha cumplido, o determinar que algo ha ocurrido si realmente no ha sido así. El milagro, podemos decir, no tiene cabida en el campo del Derecho Administrativo", a lo que se suma "el supuesto de hecho, en cuanto proviene directamente de la norma atributiva de la potestad, es siempre un elemento reglado del acto y, por tanto, perfectamente controlable por el juez"74. Una EEI lo es aunque se niegue en un boletín oficial y es un hecho indubitado el que las liberaciones oficiales de trucha arco-iris, hucho, black-bass, cangrejo señal, variedades alóctonas de trucha común y salmón atlántico, o salvelino, por citar algunos ejemplos, se han realizado y se realizan sin ninguna evaluación de sus efectos ambientales y en contra de la abundante literatura científica que prueban su carácter perjudicial para los ecosistemas fluviales españoles ${ }^{75}$.

Fuera del ámbito estricto de la UE, hay otros proyectos de países comunitarios y extracomunitarios que tratan de coordinar la actuación conjunta sobre las EEI, donde destaca el programa NOBANIS ${ }^{76}$. Por su parte, el Consejo de Europa ha intervenido también en los riesgos provocados por las EEI, mediante la propuesta de diversas "listas negras" de especies en las que ha de ponerse una atención prioritaria desde el punto de

animals and plants into the natural environment without prior risk assessment where this could harm EU biodiversity and ecosystem services (i.e. white list approach)". Es decir, la prohibición de suelta de aquellas especies incluidas por la Ciencia en las llamadas "listas negras", hecho científico que no puede ser sujeto a discrecionalidad administrativa alguna y realidad que una decisión política y burocrática no puede desconocer, pues no nos encontramos en el ámbito de los "conceptos jurídicos indeterminados", sino ante casos de la realidad determinada y concreta no sujeta por tanto a interpretación: toda especie o subespecie fuera de su hábitat original por intervención humana, intencional o no, es una especie exótica y de ellas las hay que son de modo indubitado especialmente invasoras, por lo que huelga todo ámbito de discrecionalidad administrativa por reducido que sea.

74 GARCÍA DE ENTERRÍA, E. y FERNÁNDEZ RODRÍGUEZ, T.R., Curso de Derecho Administrativo, Madrid, Civitas. Madrid, $1989^{5}$, p. 537.

75 Este mismo informe que acabamos de citar añade en su pág. 103: "A precautionary approach is particularly important in the aquatic environment, given the difficulty of carrying out an eradication once an organism has established. Member States should take appropriate regulatory or other measures to prevent introductions that may significantly impact the good ecological status of Water Framework Directive waters or the good environmental status of European marine regions. These should be the subject of consultation with neighbouring countries sharing the same river basin and, where feasible, a coordinated approach to risk management should be developed. The aquaculture Regulation does not cover e.g. release of fish for angling or use of alien live bait".

${ }^{76}$ European Network on Invasive Alien Species: www.nobanis.org. 
vista del comercio internacional ${ }^{77}$, la actividad agrícola ${ }^{78}$ así como en los efectos de la pesca recreativa en su expansión ${ }^{79}$, por medio de la Carta Europea sobre Pesca Recreativa y la Biodiversidad, de febrero de 2011, en el marco del Convenio de Berna sobre la conservación de la vida silvestre y el medio natural en Europa de 1979.

En esta Carta se pone de manifiesto la carencia de una nítida distinción en la UE entre la pesca extractiva en general y la recreativa, desde un punto de vista ecosistémico y de acuerdo con la Política Pesquera Común, tal y como lo hace el Reglamento (CE) 1224/2009, del Consejo, de 20 de noviembre de 2009, por el que se establece un régimen comunitario de control para garantizar el cumplimiento de las normas de la política pesquera común ${ }^{80}$. En virtud de este reglamento, la pesca recreativa no puede comercializar las capturas y ha de someterse a estudios de control biológico, ya que de acuerdo con el art. 1 del Reglamento 2371/2002, del Consejo, de 20 de diciembre, sobre la conservación y la explotación sostenible de los recursos pesqueros, abarca no sólo la pesca marítima, sino la que se realiza "en el territorio de los Estados miembros".

Teniendo estas cuestiones en mente, interesa destacar para terminar con este apartado dedicado a la situación en Europa con el conjunto de medidas propuestas por el Consejo de Europa en esta Carta Europea, medidas que chocan de plano con el modelo de pesca de agua dulce insostenible basado en la liberación de especies invasoras. Por su claridad e interés para los gestores de la pesca en las Comunidades Autónomas, reproducimos

\footnotetext{
77 GENOVESI, P. Y SCALERA, R., Towards a black list of invasive alien species entering Europe through trade, and proposed responses, Convention on the conservation of European wildlife and natural habitats, Estrasburgo 2007.

${ }^{78}$ HEYWOOD, V. y BRUNEL, S., Code of conduct on horticulture and invasive alien plants. Nature and Environment, Council of Europe Publishing, Estrasburgo, 2009.

79 CONSEJO DE EUROPA, European charter on recreacional fishing and biodiversity, Estrasburgo, 2011.

${ }^{80}$ Art. 55: "Los Estados miembros se asegurarán de que la pesca recreativa en su territorio y en aguas comunitarias se realice de modo compatible con los objetivos y normas de la política pesquera común”.

El art. 4 (28) define la pesca recreativa como las actividades pesqueras no comerciales que exploten recursos acuáticos vivos con fines recreativos, turísticos o deportivos. Se reconoce que "la pesca recreativa puede tener un impacto significativo en los recursos pesqueros, los Estados miembros deben asegurar que se realiza de forma compatible con los objetivos de la política pesquera común" y se afirma que "en el caso de las poblaciones sujetas a un plan de recuperación, los Estados miembros deben recoger datos relativos a las capturas de la pesca recreativa. En los casos en que dicha pesca tenga un impacto significativo en los recursos, el Consejo debe tener la posibilidad de decidir medidas específicas de gestión" (Considerando 27).
} 
textualmente en nota a pie de página su contenido, en su versión original en lengua inglesa ${ }^{81}$.

Concluimos este apartado dedicado al Derecho europeo con unas menciones al principio jurídico de precaución, dado que estos riesgos graves de las EEI, con daños probados científicamente, contravienen el principio de cautela y acción preventiva del Tratado de Funcionamiento de la Unión Europea (TFUE), cuyo art. 191.2 de la versión consolidada tras el Tratado de Lisboa (antiguo art. 174 TUE), expresa que: "La política de la Unión en el ámbito del medio ambiente tendrá como objetivo alcanzar un nivel de protección elevado, teniendo presente la diversidad de situaciones existentes en las distintas regiones de la Unión. Se basará en los principios de cautela y de acción preventiva, en el principio de corrección de los atentados al medio ambiente, preferentemente en la fuente misma, y en el principio de quien contamina paga”. Son principios jurídicos rectores y no meras admoniciones bienintencionadas, a lo que se suma el que, de acuerdo con la nueva versión del art. 11 del TFUE, se asuma el criterio adoptado por el Tribunal de Justicia de las Comunidades Europeas en su famosa sentencia "National Farmers Union I" de 5 de mayo de 1998: "las Instituciones pueden adoptar medidas de protección sin tener que esperar a que se demuestre plenamente la realidad y gravedad de tales riesgos" ${ }^{\prime \prime 2}$.

\footnotetext{
${ }^{81} 2.4$ Principle 4: Maintain populations of native species with adaptive gene pools.

2.4.1 Rationale: Native species and their habitats (and human livelihoods derived from them) can be adversely impacted by either the 1) introduction of invasive alien species that can adversely impact native stocks; or 2) human selection for traits which may jeopardise the long-term viability of their populations; and 3) artificial barriers to fish movements that can restrict migration, feeding or reproduction.
}

\subsubsection{Guidelines: Conservation will be enhanced if:}

2.4.2.1 Regulators and managers: a) prevent the release, spreading and translocation of invasive alien species that can have significant impacts on native fish populations or the environment; b) engage recreational fishers in programmes to remove invasive alien species; c) facilitate the reestablishment of originally indigenous fish species in accordance with iucnguidelines and have clear management plans that define their recovery; d) incorporate genetic considerations into management plans; e) seek transboundary cooperation to ensure genetic adaptability of populations; f) monitor the genetic characteristics of species populations of special concern.

2.4.2.2 Recreational fishers: a) favour re-stocking from appropriate sources but only introduce or reintroduce species in accordance with IUCN guidelines; b) avoid exclusively selecting for specific phenotypic or behavioural traits of individuals which are not representative of the wild species population and that can consequently be detrimental; c) aid scientists and managers in monitoring genetic characteristics of populations.

${ }^{82}$ En cuanto al Derecho sectorial de la UE sobre la biodiversidad, la STJUE, Sala $2^{\mathrm{a}}$, de 10 de enero de 2006, caso Comisión/Alemania, falló que: "El Tribunal de Justicia ya ha declarado que la exigencia de una adecuada evaluación del impacto medioambiental de un plan o de un proyecto está supeditada a la condición de que haya una probabilidad o un riesgo de que afecte de forma significativa al lugar de que se trate. Pues bien, teniendo en cuenta especialmente el principio de cautela, tal riesgo existe desde el 


\section{EL RÉGIMEN JURÍDICO Y LA GESTIÓN DE LAS ESPECIES EXÓTICAS INVASORAS EN ESPAÑA}

\section{La normativa de pesca fluvial como ilícito apoyo público a la expansión de especies exóticas invasoras.}

La regulación de las EEI en el Derecho español ha ido de la mano del Derecho internacional y comunitario, a la vez que junto a los avances científicos en la materia, como no puede ser de otra forma, lo que no obsta a la existencia de ciertas inercias que no encuentran amparo jurídico en la actualidad.

En el ámbito de la pesca y la acuicultura ${ }^{83}$, la normativa ha apoyado desde hace tiempo prácticas que han devenido obsoletas y que, sobre todo, han creado una demanda artificial de la práctica de la pesca recreativa insostenible según criterios científicos y legales contemporáneos, basada en la liberación sin más de ejemplares de peces, con orígenes en la Ley de Pesca Fluvial, de 20 de febrero de 1942, cuyo art. 28 y ss., fomentaba y fomenta la repoblación sistemática de las aguas continentales de forma anual y la creación de piscifactorías para estos fines, así como prescribía el "extirpar todos los seres que se consideren perjudiciales" para la pesca. De hecho, fue la Administración la que importó especies como el hucho o salmón del Danubio, el lucio, el black-bass, o liberó y libera de modo indiscriminado miles de ejemplares de trucha arco-iris y de variedades alóctonas de trucha común y salmón atlántico. Del mismo modo, se realizaron sueltas clandestinas particulares de especies como el siluro, la lucioperca, el pez gato, el alburno o el cangrejo rojo, por citar algunas.

Un paso más en la insostenibilidad de la pesca lo dio, ilegalmente, la propia Administración cuando a principios de los años setenta creó los llamados "cotos

\footnotetext{
momento en que no cabe excluir, sobre la base de datos objetivos, que dicho plan o proyecto afecte al lugar en cuestión de forma apreciable (véase la sentencia de 20 de octubre de 2005, Comisión/Reino Unido, C-6/04, Rec. p. I-0000, apartado 54)". Más recientemente, la STJUE (Gran Sala), de 9 de marzo de 2010, caso ERG, retoma el principio de cautela ambiental y dicta en su fallo que: "... No obstante, tal medida ha de justificarse por el objetivo de impedir la agravación de la situación medioambiental en el lugar en que se ejecutan las referidas medidas o, en aplicación del principio de cautela, por el objetivo de prevenir la aparición o reaparición de otros daños medioambientales en los referidos terrenos de los operadores, adyacentes a todo el litoral objeto de las citadas medidas reparadoras".

${ }^{83}$ Sobre el régimen jurídico de la acuicultura, vid. TEIJEIRO LILLO, Ma E., "Calidad y seguridad de los productos acuícolas", Revista Aragonesa de Administración Pública, núm 28, 2006; de esta misma autora Acuicultura marina: Régimen jurídico y ordenación ambiental, Iustel, Madrid, 2009, y Acuicultura marina: Mercado, consumo y sanidad animal, Iustel, Madrid, 2011.
} 
intensivos" sin amparo legal alguno ${ }^{84}$, pues era una categoría no regida por la Ley de Pesca de 1942, en respuesta a una llamada de socorro económico emitida por las piscifactorías de trucha arco-iris más ruinosas, creando así un tipo de pesca que por definición traspasa los límites jurídicos y biológicos de la sostenibilidad, ya que periódicamente se liberan en determinados tramos de ríos y zonas embalsadas un número de ejemplares, cuyo coste real es asumido en su práctica totalidad por el contribuyente $^{85}$, es más, la suelta intensiva de peces alóctonos de granja es a lo que se reduce la "gestión" de la pesca fluvial, con los costes de oportunidad que tal gasto de tiempo y dinero conlleva, que bien podrían dedicarse a la restauración fluvial y a lograr el buen estado ecológico de la DMA. En efecto, el art. 1 de esta Orden establecía, y aún establece para las Comunidades Autónomas regidas por la Ley de Pesca de 1942, que por parte del extinto ICONA o bajo régimen de consorcio podrían "establecerse en determinadas aguas de dominio público, cotos de pesca intensiva donde periódicamente y de forma continuada se incorporarán ejemplares adultos de truchas, de longitud superior a 19 centímetros y procedentes de cultivos intensivos, o de cualquier otra especie, siempre que dichos ejemplares sean de dimensiones legales, con el fin de disponer a disposición de los pescadores lugares donde éstos pedan realizar el ejercicio de la pesca con plenas garantías de éxito". Es decir, el objetivo oficialmente declarado era facilitar la pesca de ejemplares de granja y que carecieran de todo atisbo del instinto

\footnotetext{
${ }^{84}$ Orden de 15 de julio de 1975 , por la que se regulan dichos cotos (BOE $\mathrm{n}^{\mathrm{o}} 195$, de 15 de agosto de 1975).

${ }^{85}$ El cotejo de algunas contratas públicas de suministro de peces nos da muestra de su importancia. En la Comunidad de Madrid, amparándose en la normativa ilegal que dice desarrollar la ley de Pesca de 1942, como luego veremos, en la campaña 2009-2011 se licitó un contrato por $324.882 €$ para liberar $88.000 \mathrm{~kg}$ de truchas arco-iris en los cotos intensivos regionales, cada kilogramo pues ha supuesto un desembolso de 3'69 €, según el BOE de 12 de agosto de 2010, la cifra final fue de 324.852 euros. En La Rioja se contrató para la temporada de 2010 la suelta de $7.000 \mathrm{~kg}$ de trucha arco-iris por un valor de $30.000 €$, es decir, 4’28 por cada kg. La Junta de Andalucía contrató en 2010 la suelta de $118.600 \mathrm{~kg}$. de trucha arcoiris para las tres siguientes temporadas; de acuerdo con el pliego de condiciones técnicas del contrato NET 628709, en 2009 se licitaron $165.672 €$ para liberar $53.100 \mathrm{~kg}$ de trucha arco-iris en las provincias de Granada, Sevilla y Jaén, a un precio medio de 3'12 €/ kg.. En la temporada de 2008, la Diputación Foral de Vizcaya contrató por 94.340 '45 $€$ la suelta de esta misma especie en sus cotos intensivos, aun precio, según el tamaño del ejemplar de 5’25 €/kg y 3’70 €/kg; la cifra ascendió a 114.481'50€ en la temporada de 2005. La Junta de Castilla y León gastó solamente en los cotos intensivos de la zona oriental de la provincia de Valladolid $53.100 €$ en las campañas de 2007 y 2008, mientras que en Palencia la cifra ascendió a 40.371'10 euros para esos mismos años, a la vez que en Segovia se dedicaron $96.120 €$ para las campañas de 2008 y 2009; en 2004, en la provincia de Ávila se gastaron $24.996 €$. La Región de Murcia cada temporada de pesca ve cómo se liberan unos 50.000 ejemplares de trucha arco-iris, a un coste desconocido al no facilitarse esta información a la que se tiene derecho de acceso.
} 
de supervivencia y del recelo propio de las especies salvajes, eliminando el esfuerzo propio y tradicional de la actividad piscatoria, incluso para niños y ancianos (sic) ${ }^{86}$.

La creación, ilegal, de este tipo de cotos se debió a una remisión al art. 13 de la Ley de Pesca, que habla exclusivamente de las vedas, pero no de tipos de zonificación y aprovechamiento de la pesca, fue calificada de "sorprendente" por quien luego llegaría a ser Defensor del Pueblo, añadiendo que “en ningún caso establece, ni remotamente regula, un nuevo tipo de aprovechamiento de la riqueza piscícola, ni por tanto de la utilización del dominio público. Una cosa es decretar un período de veda más o menos extenso y otra muy distinta constituir un tipo de pesca" ${ }^{\wedge 7}$. Este autor afirmó además que "entendemos que el régimen concertado que se prevé para los cotos nacionales consorciados y los de pesca intensiva no tiene apoyatura legal alguna y es más supone una grave quiebra del régimen legal imperante" 88 . Por otro lado, el que en los cotos intensivos pudiera practicarse la pesca durante todo el año contraviene de plano los arts. 12 y ss. de la Ley de Pesca, pues con la eliminación de épocas en que no se puede pescar se han infringido e infringen, en palabras del prof. Gil-Robles, “escandalosamente el mandato imperativo de la Ley de Pesca de 1942 de respetar las épocas de veda y que como vimos no admite excepciones de ningún tipo para con los cotos, sean del tipo que sean...Negar la protección de las épocas de veda en estos casos es no sólo una monstruosidad atentatoria al respeto mínimo de las leyes de la naturaleza sino también, insisto, una infracción notoria de la Ley de Pesca Fluvial»"89.

\footnotetext{
${ }^{86}$ Impropia de los poderes públicos nos parece esta referencia a los niños y ancianos como destinatarios de esta medida, lo que cual se publica sin pudor alguno en el BOE a pesar de ser una decisión claramente dirigida a apoyar a un sector económico privado con dinero público a fondo perdido, un claro ejemplo de "subvención perversa", pues afecta en grado sumo a la economía, al riesgo empresarial, a la libre competencia y a la objetividad y transparencia de la Administración, así como al medio ambiente. Vid. MYERS, NORMAN y KENT, JENNIFER (2001): Perverse subsidies. How tax dollars can undercut the environment and the economy, Island Press, Washington DC, 2001. DE MOOR, A., Subsidizing unsustainable development. Undermining the earth with public funds, Earth Council, La Haya, 1997. ROODMAN, D.M., Paying the piper. Subsidies, politics, and the environment, Worldwatch Institute, Washington DC, 1996. BRUFAO CURIEL, P., Subvenciones agrarias, desarrollo rural y medio ambiente, Comares, Granada, 2007.

${ }^{87}$ GIL-ROBLES, A., "El ejercicio del derecho de pesca en aguas continentales: en torno a los cotos intensivos de pesca", Revista Española de Derecho Administrativo, núm. 7, 1975, pp. 594 y 595. Otros estudios jurídicos sobre la pesca fluvial: FANLO, A., "La pesca fluvial. Algunos criterios para articular su protección jurídica”, Cosculluela, L. (coord..), Estudios de Derecho Público Económico, Civitas, Madrid, 2003. GARRIDO, N., "Pesca fluvial", Embid, A. (coord..), Diccionario de Derecho de Aguas, Iustel, Madrid, 2007.

${ }^{88}$ Id., p. 604.

${ }^{89}$ Id., p. 600.
} 
La misma carencia de apoyo legal se predicaba de los cotos nacionales de pesca del Decreto de 15 de enero de 1954 y que se intentaron "convalidar" mediante la creación de una tasa en virtud del Decreto de 2 de junio de 1960, desarrollo de la Ley de Tasas y Exacciones Parafiscales de 26 de diciembre de 1958, ante lo cual este mismo autor añade que "la convalidación por carambola no creo que pueda ser mantenida en este caso y, por tanto, es perfectamente cuestionable la legalidad de las disposiciones creadoras de esos cotos nacionales y de toda la actuación administrativa consecuencia de ello" ${ }^{90}$. El caso de los cotos consorciados ${ }^{91}$, generalmente intensivos, es aún más grave, pues se crearon y rigieron por una simple circular ${ }^{92}$. Es decir, buena parte de la normativa y práctica de la pesca fluvial en España ha sido y es ilegal de modo patente, como sucede en Cataluña ${ }^{93}$, lo que además ha creado el problema de las recurrentes sueltas intensivas de especies alóctonas como la trucha arco-iris, calificada científicamente $^{94}$ y sin lugar a dudas como una de las cien más dañinas por la Unión Internacional de Conservación de la Naturaleza $(\mathrm{UICN})^{95}$ y se encuentra en la

\footnotetext{
${ }^{90}$ Id., p. 596.

91 Sobre los intentos privatizadores de la pesca fluvial recreativa, basada generalmente en especies depredadoras alóctonas, vid. BRUFAO CURIEL, P., "Régimen jurídico de la pesca fluvial en Andalucía, ¿regreso a los derechos señoriales de pesca?”, Revista Andaluza de Administración Pública, núm. 65, 2007.

92 De carácter interno, $\mathrm{n}^{\circ} 10$ del ICONA, de 16 de marzo de 1973, es decir, mediante una norma no publicada oficialmente y, por tanto, secreta.

93 Dado el juego de la Disposición Final $1^{\text {a }}$ de la Ley 22/2009, de 23 de diciembre, de ordenación sostenible de la pesca en aguas continentales, por la que sigue en vigor la Ley de Pesca de 1942, pues hasta la fecha se carece de un Plan de ordenación y del reglamento de desarrollo: "Hasta que no se aprueben el Plan de ordenación de la pesca en aguas continentales y el reglamento de desarrollo de la presente ley, se mantiene vigente lo dispuesto por la Ley de regulación de la pesca fluvial, de 20 de febrero de 1942, y su reglamento de desarrollo, aprobado por el Decreto de 6 de abril de 1943". Por tanto, al ser ilegales los cotos intensivos bajo la Ley de 1942, son igual de ilegales en Cataluña, por lo cual pueden derivarse diferentes tipos de responsabilidad de todo orden jurisdiccional.

${ }^{94}$ El destacado ictiólogo del Museo Nacional de Ciencias Naturales, del CSIC, afirma en una entrevista: "Ignacio Doadrio, investigador del CSIC, coordinador del Libro Rojo mencionado y experto en peces continentales, asegura que no existe un solo cientifico que firme un estudio que diga que las sueltas de trucha arco iris no influyen en el ecosistema y que la especie no compite y desplaza a otros peces en su alimentación", en El País, 17 de abril de 2010: "Peces sospechosos: La trucha arco iris es americana, pero campa a sus anchas en los ríos españoles. Como ella, otras especies piscícolas foráneas acogotan a las autóctonas y se adueñan de su territorio". DOADRIO, I. (dir.): Atlas y libro rojo de los peces continentales de España, Ministerio de Medio Ambiente y Consejo Superior de Investigaciones Científicas, Madrid, 2002.
}

\footnotetext{
95 "Invasive Species Specialist Group" de la UICN, cuya "Global invasive species database. 100 of the world's worst invasive alien species", disponible en www.issg.org, dice: "Oncorhynchus mykiss (rainbow trout) are one of the most widely introduced fish species in the world. Native to western North America, from Alaska to the Baja Peninsula, Oncorhynchus mykiss have been introduced to numerous countries for sport and commercial aquaculture. Oncorhynchus mykiss is highly valued as a sportfish, with regular stocking occurring in many locations where wild populations cannot support the pressure from anglers.
} 
denominada, en una publicación oficial, "lista negra" de especies invasoras del Ministerio de Medio Ambiente ${ }^{96}$.

\section{El cambio de rumbo en la protección jurídica de la biodiversidad autóctona}

A pesar de la constatación de los efectos de estas especies y teniendo en cuenta la previsión del Convenio de Berna de 1979, no es hasta 1989 cuando se habla con claridad de la necesidad de ciertas restricciones a la hora de la liberación de las especies alóctonas, en relación con la caza y la pesca, en el art. 34 de la Ley 4/1989, de 27 de marzo, de conservación de los espacios naturales y de la flora y fauna silvestres, pues muchas de éstas se realizaban y realizan en espacios naturales protegidos ${ }^{97}$. Con una

Concerns have been raised about the effects of introduced trout in some areas, as they may affect native fish and invertebrates through predation and competition".

96 Es por consiguiente una materia que, repetimos, queda al margen de toda decisión discrecional administrativa, como hemos afirmado más arriba, por lo que su liberación en el medio natural no encuentra amparo jurídico alguno, pues, recordemos, la Administración no puede obrar el milagro jurídico y científico de convertir una especie invasora en una especie inocua en un ecosistema que no le es propio. CAPDEVILLA ARGÜELLES, L., et al., Especies exóticas invasoras. Diagnóstico y bases para la prevención y el manejo, Ministerio de Medio Ambiente. OAPN. Madrid, 2006. CONFEDERACIÓN HIDROGRÁFICA DEL DUERO., Manual de las especies exóticas invasoras de los ríos y riberas de la Cuenca Hidrográfica del Duero, León, 2011.

${ }^{97}$ Algunos cotos intensivos de la Comunidad de Madrid se encuentran en Lugares de Importancia Comunitaria (LIC), pertenecientes a Red Natura 2000: "Cuenca del río Guadarrama", "Cuenca del río Lozoya y Sierra Norte", “Cuencas de los ríos Alberche y Cofio" y "Cuenca del río Manzanares". En estos espacios existen inventariadas varias especies de peces de interés comunitario que pueden ser los taxones más perjudicados por la suelta masiva de truchas arco-iris, bien por depredación bien por competencia directa por los recursos tróficos, así como por transmisión de zoonosis como la saprolegnia. Entre estas especies se encuentran la colmilleja (Cobitis paludica), el calandino (Squalius alburnoides), la boga de río (Chondostroma polylepis), la pardilla (Chondrostoma lemmingii), la boga del Tajo (Pseudochondostroma polylepis), el barbo comizo (Barbus comiza) y la bermejuela (Chondrostoma arcasii). En Castilla-La Mancha hay cotos intensivos que, entre otros espacios naturales, se encuentran en los LICs y ZEPAs de la Sierra de Segura y Alcaraz, Cañones del Segura y del Mundo, Hoces del río Júcar, Hoces del río Cabriel, Alto Tajo, Riberas del Henares, Montes de Toledo y Quejigares de Barriopedro y Brihuega. En Andalucía se da el inaceptable caso de la existencia de cotos intensivos no solo en LICs y ZEPAs, sino además en contra de la propia normativa de ordenación de los recursos naturales de algunos Parques Naturales, como el de Cazorla, cuyo Plan de Ordenación de Recursos Naturales, aprobado por el Decreto 227/1999, de 15 de noviembre, dice (art. 44): "Se prohíbe la introducción, traslado o suelta de especies exóticas de la fauna silvestre, entendiendo por tales todas aquellas especies, subespecies y variedades que no pertenezcan o hayan pertenecido históricamente a la fauna del Parque Natural", a lo que se añade por el art. 116.2, en clara contradicción con lo anterior: "No se autorizará la introducción de especies no autóctonas, incluida la trucha arco iris, en los tramos fluviales donde existan ejemplares de trucha común", olvidando la afección a los tramos fluviales habitados por ciprínidos y a todo el macrobentos y flora acuática. Lo expresado en esta última norma, limitar la suelta de truchas arco-iris a tramos ciprinícolas, se intenta hacer ver como "argumento" por los defensores de los cotos intensivos, olvidando que, por ejemplo, la liberación de lince boreal o del puma en la Península Ibérica no sólo afectaría al lince ibérico, otro felino, reducido a unas poblaciones muy menguadas, sino a toda la calidad ambiental del ecosistema, de ahí la falacia de dicha opinión. El Decreto 90/2006, de 18 de abril, que aprueba el PORN y el PRUG del Parque Natural de Grazalema, en el que se encontraba hasta hace muy poco un coto intensivo de trucha arco-iris, dice en su punto 3.2.2.7: "Se fomentará la pesca de las especies exóticas con vistas a su eliminación progresiva de este espacio, así como la pesca sin muerte de las especies autóctonas para permitir la recuperación de sus poblaciones". La Orden de 21 de diciembre de 2009, por la que se fijan y regulan las vedas y períodos hábiles de pesca continental en la 
década de retraso se empieza tímidamente a poner coto a las invasoras, llevándose a cabo ciertos avances desde el punto de vista del sector público, como el cese en las sueltas de ejemplares alóctonos de trucha $\operatorname{común}^{98}$ y salmón atlántico o el comienzo de descastes de lucios (Esox lucius) en ciertos ríos castellanos y la erradicación del salvelino (Salvelinus fontinalis) en el Parque Natural de Peñalara (Madrid) ${ }^{99}$, trabajos que coinciden con la llegada clandestina a nuestros ecosistemas, de la mano de particulares, de una larga retahíla de especies ícticas invasoras, objeto de un creciente negocio de la pesca recreativa y fomentada por diversas empresas ${ }^{100}$.

Se puede considerar un punto de inflexión la inclusión en el Código Penal de 1995 (CP) del tipo de la liberación de especies exóticas ${ }^{101}$, La duda jurídica está en considerar esta disposición un delio imprudente o doloso ${ }^{102}$, dejando a un lado el agravamiento de la pena si afectan a espacios protegidos ${ }^{103}$, teniendo en cuenta además que en la práctica totalidad de los casos, cuando hablamos de pesca recreativa, las sueltas de EEI se realizan ex profeso y con tal fin por particulares o por Administraciones públicas, mientras que los escapes de centros de acuicultura por inundaciones, al encontrase en zonas inundables, o por fugas suponen una imprudencia inadmisible hoy en día, siendo

Comunidad Autónoma de Andalucía (BOJA de 21 de enero de 2010) recogía este coto intensivo. En Aragón, por citar solo la provincia de Teruel, existían en 2009 cotos intensivos en los LICs de los Estrechos del Guadalaviar y en las Muelas del Jiloca, así como en las ZEPAs del Alto Turia y del Guadalope. Huelga decir que tampoco se han evaluado según la normativa de impacto ambiental sus afecciones a la Red Natura 2000.

98 PLÁ y ZANUI, C., "Diversidad genética de la trucha autóctona española", Ríos con Vida, núm. 75, 2004.

${ }^{99}$ www.parquenaturalpenalara.org.

${ }^{100}$ Sobre las buenas prácticas en la gestión de la pesca en aguas dulces, vid. GARCÍA DE JALÓN, D. y SCHMIDT, G. (coords.), Manual práctico para la gestión sostenible de la pesca fluvial, AEMS, Madrid, 1995.

${ }^{101}$ Cuyo art. 333, en su redacción dada por la Ley Orgánica 5/2010, de 22 de junio, declara: "El que introdujera o liberara especies de flora o fauna no autóctona, de modo que perjudique el equilibrio biológico, contraviniendo las leyes o disposiciones de carácter general protectoras de las especies de flora o fauna, será castigado con la pena de prisión de cuatro meses a dos años o multa de ocho a veinticuatro meses y, en todo caso, inhabilitación especial para profesión u oficio por tiempo de uno a tres años". Al tipo penal del art. 333, habría que sumar, en el caso de sueltas de EEI realizadas por la Administración, los tipos penales del art. 404 (prevaricación), de los arts. 432, 433 y 436 (malversación y fraudes y exacciones ilegales), así como los relativos (arts. 390 y ss.) a la integridad de los documentos públicos de control de estas sueltas de peces, dada la falta real y no infrecuente de control administrativo y tributario en los cotos intensivos consorciados.

${ }^{102}$ MUÑOZ LORENTE, J., "Los delitos relativos a la flora, fauna y animales domésticos (o de cómo no legislar en Derecho Penal y cómo no incurrir en despropósitos jurídicos)", Revista de Derecho Penal y Criminología, núm. 19, 2007. RAMOS VÁZQUEZ, J. A., "Comentario al artículo 333 del Código Penal”, en Faraldo Cabana, P. (dir.): Ordenación del territorio, patrimonio histórico y medio ambiente en el Código Penal y la legislación especial, Tirant lo Blanch, Valencia, 2011.

${ }^{103}$ Art. 338 del CP. 
otra cuestión totalmente diferente de las sueltas de mascotas exóticas, claramente imprudentes por lo general. Son claramente dolosas, por otro lado, las perniciosas sueltas de animales exóticos criados en granjas peleteras por grupos animalistas, como el visón americano, o los intentos ilegales de reintroducción de especies que una vez medraron en los ecosistemas acuáticos de la Península Ibérica, como el castor europeo (Castor fiber $)^{104}$. En todo caso, transcurrieron muchos años con esta norma penal en vigor hasta que gracias a denuncias elevadas ante las Fiscalías de Medio Ambiente a partir del año 2009 se hubiera logrado demostrar la utilidad relativa de las medidas penales, pues han servido de acicate para suspender ipso facto las sueltas de trucha arcoiris en Aragón ${ }^{105}$, a la vez que han acelerado la desaparición progresiva de los cotos intensivos de pesca en Andalucía. Los efectos administrativos de la intervención penal ambiental conllevan, asimismo, la nulidad de los actos administrativos relacionados con estas liberaciones de $\mathrm{EEI}^{106}$.

El verdadero golpe de timón en pro de la biodiversidad afectada por las especies invasoras ${ }^{107}$ se ha dado con la Ley 42/2007, de 13 de diciembre, del Patrimonio Natural y de la Biodiversidad, que entró en vigor el día 15 de diciembre de 2007. Esta Ley define las EEI como "la que se introduce o establece en un ecosistema o hábitat natural o seminatural y que es un agente de cambio y amenaza para la diversidad biológica nativa, ya sea por su comportamiento invasor, o por el riesgo de contaminación genética", siendo esta última cuestión a la hora de valorar la hibridación entre distintas poblaciones de una misma especie, como la trucha común.

Por otro lado y bajo el epígrafe "Garantía de conservación de especies autóctonas silvestres", el art. 52.2 ordena lo siguiente: "Las Administraciones públicas competentes

104 DIRECCIÓN GENERAL DE MEDIO AMBIENTE DE LA RIOJA et al., "Más sobre el castor europeo en la cuenca del Ebro", en Quercus, núm. 314, 2012.

${ }^{105}$ Cuestión que reflejaba la Orden de 16 de marzo de 2011, del Consejero de Medio Ambiente, por la que se aprueba el Plan General de Pesca de Aragón para el año 2011 (BOA de 17 de marzo de 2011), en cuya exposición de motivos se incluía de modo inaceptable una referencia explícita a la entidad que denunció por la vía penal los hechos, es decir, se "acusaba" a una entidad de pescadores conservacionistas por denunciar la posible vulneración de la Ley penal. Elevada posteriormente una queja al Justicia de Aragón, esta mención se retiró en una nueva publicación de la Orden de Vedas.

${ }^{106}$ Son nulos de pleno Derecho los actos administrativos de autorización de acuerdo con el art. 62. 1. d) de la Ley 30/1992, del Régimen Jurídico de las Administraciones Públicas y del Procedimiento Administrativo Común: "Los actos de las Administraciones públicas son nulos de pleno derecho en los casos siguientes: Los que sean constitutivos de infracción penal o se dicten como consecuencia de ésta".

${ }^{107}$ Puede consultarse este informe para obtener una idea cabal de lo realizado en España: COMISIÓN EUROPEA, A comparative assessment of existing policies on invasive species in the EU member states and in selected OECD countries. Country assessment, Bruselas, 2011, ya citado más arriba. 
prohibirán la introducción de especies, subespecies o razas geográficas alóctonas cuando éstas sean susceptibles de competir con las especies silvestres autóctonas, alterar su pureza genética o los equilibrios ecológicos”. A su vez, el art. 61 crea la importante herramienta del Catálogo Español de $\mathrm{EEI}^{108}$, que por su interés reproducimos textualmente ${ }^{109}$ y del que destacamos que este catálogo conlleva la prohibición genérica de posesión, transporte, tráfico y comercio de ejemplares vivos o muertos, de sus restos o propágulos, incluyendo el comercio exterior ${ }^{110}$.

En cuanto a la actividad piscatoria ${ }^{111}$, el art. 62.3 e) dicha Ley ordena, además: "En relación con la actividad cinegética y acuícola, queda prohibida la introducción de

${ }^{108}$ Incluido en el Capítulo III de esta Ley: "Prevención y control de las especies exóticas invasoras”.
${ }^{109}$ El artículo 61 regula el Catálogo Español de Especies Exóticas Invasoras: “1. Se crea el Catálogo Español de Especies Exóticas Invasoras, cuya estructura y funcionamiento se regulará reglamentariamente y en el que se incluirán, cuando exista información técnica o científica que así lo aconseje, todas aquellas especies y subespecies exóticas invasoras que constituyan una amenaza grave para las especies autóctonas, los hábitats o los ecosistemas, la agronomía o para los recursos económicos asociados al uso del patrimonio natural. Depende del Ministerio de Medio Ambiente, con carácter administrativo y ámbito estatal. 2. La inclusión de una especie en el Catálogo Español de Especies Exóticas Invasoras se llevará a cabo por el Ministerio de Medio Ambiente, a propuesta de la Comisión Estatal para el Patrimonio Natural y la Biodiversidad, previa iniciativa de las Comunidades autónomas o del propio Ministerio, cuando exista información técnica o científica que así lo aconseje. Cualquier ciudadano u organización podrá solicitar la iniciación del procedimiento de inclusión o exclusión de una especie o subespecie, acompañando a la correspondiente solicitud una argumentación científica de la medida propuesta. 3. La inclusión en el Catálogo Español de Especies Exóticas Invasoras conlleva la prohibición genérica de posesión, transporte, tráfico y comercio de ejemplares vivos o muertos, de sus restos o propágulos, incluyendo el comercio exterior. Esta prohibición podrá quedar sin efecto, previa autorización administrativa, cuando sea necesario por razones de investigación, salud o seguridad de las personas. 4. Por parte de las Comunidades autónomas se llevará a cabo un seguimiento de las especies exóticas con potencial invasor, en especial de aquellas que han demostrado ese carácter en otros países o regiones, con el fin de proponer, llegado el caso, su inclusión en el Catálogo Español de Especies Exóticas Invasoras. 5. El Ministerio de Medio Ambiente y las Comunidades autónomas, en el marco de la Comisión Estatal del Patrimonio Natural y la Biodiversidad, elaborarán Estrategias que contengan las directrices de gestión, control y posible erradicación de las especies del Catálogo Español de Especies Exóticas Invasoras, otorgando prioridad a aquellas especies que supongan un mayor riesgo para la conservación de las fauna, flora o hábitats autóctonos amenazados, con particular atención a la biodiversidad insular. La Conferencia Sectorial de Medio Ambiente, a propuesta de la Comisión Estatal para el Patrimonio Natural y la Biodiversidad, y previo informe del Consejo Estatal para el Patrimonio Natural y la Biodiversidad, aprobará estas estrategias, que tendrán carácter orientativo. 6. Las Comunidades Autónomas, en sus respectivos ámbitos territoriales, podrán establecer catálogos de Especies Exóticas Invasoras". Vid. asimismo el dictamen del Consejo de Estado 913/2007, de 17 de mayo de 2007, sobre el anteproyecto de Ley del Patrimonio Natural y de la Biodiversidad.

${ }^{110}$ Reiteramos que la discrecionalidad administrativa se ve reducida a su mínima expresión o incluso eliminada del todo cuando se trata de las especies incluidas en estudios científicos indubitados, sobre todo los que incluyen las ya conocidas como "listas negras" u otras bajo terminología similar (i.e. "las cien especies mas dañinas"), es decir, abunda la literatura científica y técnica al respecto GALERA RODRIGO, S., "Los instrumentos del derecho de la técnica: su consideración desde la técnica normativa", Rosado Pacheco, S. (dir.), Derecho europeo comparado sobre la Ley y el Reglamento, CEURA, Madrid, 2003.

${ }^{111}$ ELVIRA, B., "Impacto y control de los peces exóticos introducidos en España”, Granado Lorencio, C. (ed.), Conservación, recuperación y gestión de la ictiofauna continental ibérica, Estación de Ecología Acuática, Sevilla, 1997. 
especies alóctonas. En el caso de introducciones accidentales o ilegales, no se podrá autorizar en ningún caso su aprovechamiento cinegético o piscícola, promoviendo las medidas apropiadas de control de especies para su erradicación" ${ }^{\text {112 }}$. A pesar de este claro mandato, numerosas CC.AA. han seguido liberando ejemplares de especies alóctonas, principalmente trucha arco-iris, incluso aprobando cupos máximos de capturas y tallas mínimas ${ }^{113}$.

\section{El Real Decreto de Especies Exóticas Invasoras y la disputa sobre las especies ícticas, la pesca recreativa y la acuicultura}

Ligando actividad cinegética y piscatoria con el catálogo de EEI, hay que traer a colación el Real Decreto 1628/2011, de 14 de noviembre, por el que se regula el listado y catálogo español de especies exóticas invasoras ${ }^{114}$. Una de las cuestiones jurídicas más importantes es la creación sin amparo legal alguno del llamado "Listado de especies exóticas con potencial invasor". La remisión normativa al desarrollo vía reglamentaria del Catálogo de Especies Exóticas Invasoras no puede permitir el hecho de que se incluyan dos categorías: el "catálogo" y el "listado", ambos con un rigor diferente por el cual el listado va en contra de la normativa internacional y nacional

\footnotetext{
${ }^{112}$ La prohibición del aprovechamiento pesquero cuenta con la lógica siguiente: dado que quienes realizan sueltas de EEI esperan poder capturarlas a posteriori o abrir negocios con el fin de lucro correspondiente, cerrar esa posibilidad imposibilitando su pesca o caza legalmente supone un desincentivo a su liberación en el medio natural. El País de 7 de noviembre de 2011: "El siluro acecha el Guadalquivir". El alcalde de Alcántara (Cáceres) explicaba ante la presencia del siluro en el embalse homónimo: El nuevo puerto deportivo dará un gran impulso a nuestro municipio y nos permitirá aprovechar la máximo el gran potencial que tenemos", manifestó. Así también, Muñoz auguró que el pantano registrará un auge importante en los próximos años ya que sus aguas cuentan con dos nuevas especies no autóctonas -siluro y lucioperca- que tienen mucha aceptación entre pescadores que proceden del extranjero con alto poder adquisitivo. "Desde hace un tiempo hemos notado una importante afluencia en Alcántara de ciudadanos franceses, noruegos, finlandeses e ingleses que vienen hasta aquí para pescar atraídos por las especies no autóctonas", en El Periódico de Extremadura de 4 de enero de 2012. Por tanto, no es válida la previsión del art. 19.2 de la Ley 11/2010, de 16 de noviembre, de pesca y acuicultura regional, por la que las EEI "podrán ser objeto de medidas de gestión para facilitar su control, pudiendo la Consejería con competencia en materia de pesca autorizar su captura en determinados tramos o masas de agua, así como aquellas otras medidas que se determinen". Vid. Brufao Curiel, Pedro y Cordero Pedrazo, Pedro: La nueva Ley de Pesca de Extremadura, Hoy de 5 de octubre de 2010.
}

\footnotetext{
113 Siendo paradigmáticos el caso de Madrid o el de Murcia. Vid. la Orden de 10 de mayo de 2011 por la que se regula el ejercicio de la pesca fluvial para la temporada 2011/2012 y reglamentaciones para la conservación de la fauna ictícola de la Comunidad Autónoma de la Región de Murcia. (BORM de 14 de mayo del 2011). En Murcia se liberaron 50.000 ejemplares de trucha arco-iris en la temporada anterior. Criticamos la falta de adopción de medidas cautelares de suspensión de esta Orden por parte del TSJ de Murcia en el recurso contra la misma. Brufao Curiel, Pedro: Sin medidas cautelares no hay Justicia, ABC de 24 de agosto de 2009; de este mismo autor y sobre las medidas cautelares: "El Estado de Derecho y el honor de la Justicia: El medio ambiente como termómetro jurídico de la ética pública”, El Cronista del Estado Social y Democrático de Derecho, núm. 25, 2012.
}

${ }^{114}$ Sometido al dictamen del Consejo de Estado $n^{\circ}$ 1756/2011, de 10 de noviembre de 2011. 
superior, ya que permite un cierto fomento de algunas especies exóticas invasoras. La gravedad de este asunto implica que por un lado, se infringe el principio de jerarquía normativa y, por otro, se quiebra el principio jurídico que indica que "donde no se distingue no se ha distinguir": Si la Ley 42/2007, de Patrimonio Natural y de la Biodiversidad, no distingue entre catálogo y listado, el RD de desarrollo no tiene por qué distinguir y rebajar, de este modo sorprendente, la conservación de la biodiversidad que se predica del Título III, sobre todo a los efectos de su art. 61.3, ya citado. Por ejemplo, tanto el hucho, como la trucha arco-iris, el cangrejo rojo, el esturión del Adriático o el esturión siberiano, de reconocido e indubitado efecto invasor, son objeto de tráfico y transporte en la actualidad y, casualmente, se han incluido bajo el amparo de las disposiciones transitorias del Real Decreto ${ }^{115}$. Es decir, el RD no puede, por tanto, crear un "listado" no previsto por la Ley 42/2007, so pena de nulidad, es decir, creando ex novo materias y sobrepasando los límites materiales y jurídico marcados por la Ley y por nada menos que nuestro sistema de fuentes del Derecho, nulidad que se predica del art. 62.2 de la Ley 30/1992, del Régimen Jurídico de las Administraciones Públicas $^{116}$.

Las incongruencias del RD de EEI se subraya acerca de las cuestiones materiales, lo que afecta de hecho a la biodiversidad es el que ejemplares de ciertas especies clasificadas de un modo u otro por la Ciencia afecten a la calidad ambiental y biológica de una zona $^{117}$. Por tanto, en aras de la defensa del bien jurídico de la biodiversidad, no importa que hablemos de que unas "especies" se encontrasen en España con anterioridad a la promulgación de la Ley con fines cinegéticos o piscatorios, sino de que sus ejemplares medren en nuestros ecosistemas. Si de salvaguardar la biodiversidad se trata, veremos

\footnotetext{
${ }^{115}$ De ahí que rechacemos de modo categórico la supuesta justificación contenida en la Exposición de Motivos del Real Decreto de EEI: "Como paso previo a la catalogación, se ha considerado conveniente establecer un Listado de especies exóticas con potencial invasor, en el que podrán incluirse todas aquellas que cumplan o puedan cumplir las condiciones establecidas en el artículo 61.4 de la citada Ley”.

116 “También serán nulas de pleno derecho las disposiciones administrativas que vulneren la Constitución, las leyes u otras disposiciones administrativas de rango superior, las que regulen materias reservadas a la Ley, y las que establezcan la retroactividad de disposiciones sancionadoras no favorables o restrictivas de derechos individuales". A su vez, el art. 23.2 de la Ley 50/1997, del Gobierno, se muestra tajante al afirmar que los reglamentos no podrán regular materias objeto de reserva de ley, ni infringir normas con dicho rango, algo que deriva del art. 9.3 de nuestra Constitución, que garantiza la jerarquía normativa.

${ }^{117}$ La Disposición adicional segunda del RD de EEI dice: "La autoridad competente podrá considerar como especies exóticas invasoras a efectos de la aplicación de las medidas de lucha contra las especies exóticas invasoras contempladas en el artículo 10: a. Los ejemplares híbridos de especies, subespecies y razas geográficas alóctonas que se encuentren en libertad en el medio natural. Si el ser un híbrido es una cuestión especial de la generalidad de ser alóctono, entonces también habría de aplicársele el régimen jurídico de las EEI, sin que la discrecionalidad administrativa se predicara de estos casos".
} 
que hay gravísimos perjuicios causados por las introducciones que un día fueron legales o las realizó la Administración por la vía de hecho y que todavía se siguen realizando. El régimen de disposiciones transitorias ${ }^{118}$ del RD de EEI incumple de plano lo previsto en el art. 62.3 e) de la Ley ${ }^{119}$. Las razones jurídicas son las siguientes: en primer lugar, la Ley no habla de las introducciones legales anteriores, por lo que no se debe distinguir donde la Ley no distingue, como hemos visto, ante lo cual se aplican los postulados principales de la Ley, cual es la protección de la biodiversidad en todo el territorio nacional y no sólo donde actualmente no existan dichas especies. Aceptar lo contrario da como resultado el que el reglamento rebajara el nivel de protección otorgado por la Ley, así como favorecer en la práctica la expansión de especies alóctonas desde sus actuales lugares. El juego de las disposiciones transitorias con los anexos nos lleva al vaciamiento del contenido normativo de la Ley, algo inadmisible en un Estado de Derecho.

Un mero análisis de estos anexos prueba lo que decimos. En el Catálogo y en el Listado se acogen a esa excepción de las disposiciones transitorias, que entendemos ilegal, el cangrejo señal $^{120}$, el cangrejo rojo americano ${ }^{121}$, la trucha arco-iris, el carpín dorado, el

\footnotetext{
${ }^{118}$ Disposición transitoria segunda: "Especies introducidas con anterioridad a la entrada en vigor de la Ley 42/2007, de 13 de diciembre, con fines cinegéticos, piscícolas y silvícolas: Para las especies incluidas en el Catálogo y en el Listado presentes en el medio natural e introducidas legalmente con fines de caza, pesca o selvicultura, antes de la entrada en vigor de la Ley 42/2007, de 13 de diciembre, que figuran específicamente como tales en los anexos, y con objeto de evitar que se extiendan más allá de su área de distribución actual, su gestión, control y posible erradicación se podrá realizar a través de la caza, la pesca o la selvicultura en el marco de estrategias a tal efecto. Con el objeto de limitar su expansión, las comunidades autónomas y ciudades de Ceuta y Melilla deberán elaborar una delimitación cartográfica adecuada y específica del área donde se aplicará esta disposición, dentro del área de distribución de la especie que figura en el Inventario Español del Patrimonio Natural y la Biodiversidad, considerando exclusivamente su área de procedencia legal autorizada y de posterior expansión natural. Esta información deberá ser remitida a la Comisión Estatal del Patrimonio Natural y la Biodiversidad, para su conocimiento e informe, previamente a su aprobación, en el marco de la correspondiente estrategia dirigida a tal finalidad. Para las especies introducidas ilegalmente antes de la entrada en vigor de la Ley 42/2007, de 13 de diciembre, e incluidas en el Catálogo y en el Listado, y aquellas introducidas legalmente detectadas fuera de sus áreas de distribución autorizadas, se podrán emplear artes y métodos de caza, pesca o selvicultura, en la ejecución de las actividades previstas para su posible erradicación. Cuando se compruebe, previa consulta al Comité Científico, que la actividad cinegética, piscícola o selvícola de una especie citada en esta disposición, está fomentando su expansión y establecimiento fuera de su área de distribución actual, la Dirección General de Medio Natural y Política Forestal informará a las comunidades autónomas o ciudades de Ceuta y Melilla para que adopte las medidas oportunas conducentes al fin de este aprovechamiento".
}

119 "En relación con la actividad cinegética y acuícola, queda prohibida la introducción de especies alóctonas. En el caso de introducciones accidentales o ilegales, no se podrá autorizar en ningún caso su aprovechamiento cinegético o piscícola, promoviendo las medidas apropiadas de control de especies para su erradicación".

${ }^{120}$ A pesar de la vigencia del RD de EEI, que incluye el cangrejo señal en el Catálogo, Navarra ha aprobado medidas de protección para esta especie invasora, como cotos y cupos, que adolecen como no puede ser de otro modo de nulidad radical de pleno Derecho. Vid. Orden Foral 89/2012, de 27 de febrero, 
hucho, el lucio, el salvelino, la perca americana, el muflón ${ }^{122}$ y el arruí. Resulta curioso por lo demás, que una misma especie deje de ser invasora por una cuestión burocrática, cuando fue importada por la Administración, o que sea invasora en una provincia y en otra no, criterio también burocrático que no puede desconocer la realidad biológica. En algunos casos, como el del black-bass o perca americana, su introducción llegó de la iniciativa de la Administración, pero su expansión posterior se ha debido a sueltas incontroladas de particulares, muestra patente de limitar los efectos reales de una especie a una antigua práctica administrativa, es decir no existe correspondencia alguna entre el área de distribución actual con el área original de introducciones autorizadas o realizadas por la Administración ${ }^{123}$. Sigamos con el problema de que una norma que pretende conservar la biodiversidad aleje de sus objetivos precisamente las especies que más han contribuido a la pérdida de la biodiversidad acuática, la más afectada: El cangrejo señal y el rojo son transmisores del hongo que arrasó las poblaciones de

de la Consejera de Desarrollo Rural, Industria, Empleo y Medio Ambiente, por la que se establece la normativa específica que regirá la pesca en Navarra durante el año 2012, incluyendo determinadas medidas de control de poblaciones de especies exóticas invasoras (BON n 47 de 7 de marzo de 2012).

${ }^{121}$ Especie objeto de la Sentencia del Tribunal Constitucional 66/1991, de 6 de marzo, recaída ante un recurso de la Abogacía del Estado contra una Orden de Castilla y León que prohibía la comercialización del cangrejo alóctono para proteger la especie autóctona, alegando restricciones no justificadas a la libertad de comercio y la propiedad privada. El TC declaró, de modo diferente al caso alemán comentado en este trabajo, que: "la prohibición de comerciar se procurara fuese tan sólo evitar la introducción fraudulenta en masas de agua fluvial de la Comunidad Autónoma de especies vivas de cangrejo de río apestadas. Pero, al lado de esta finalidad y en estrecha relación con ella, la Administración autonómica persigue también, como así resulta con claridad del preámbulo de la Orden de 7 de enero de 1988, la preservación de la especie autóctona del cangrejo de río, afectada ella misma de afanomicosis y de la que, a juzgar por el informe técnico que la representación de la Junta de Castilla y León acompaña a sus alegaciones, no parecen subsistir en la Comunidad demasiadas unidades. Y desde esta doble finalidad no cuesta apreciar entre la prohibición de comerciar y los objetivos que han llevado a establecerla una relación de desmesurada adecuación de medios a fin, pues, de no ser por la primera quedaría el segundo notablemente comprometido, por cuanto el libre comercio con cangrejos de río vivos podría tener para los autóctonos, ya de por sí escasos consecuencias que, sumadas a las derivadas del contagio de la afanomicosis, no serían fácilmente reparables y podrían ocasionar en el ecosistema fluvial de la Comunidad graves perjuicios".

${ }^{122}$ Ya se han aprobado proyectos de erradicación en Extremadura: Resolución de 27 de diciembre de 2010, de la Dirección General del Medio Natural, por la que se aprueba el plan de erradicación del muflón en el Parque Natural Tajo Internacional (DOE de 18 de enero de 2011).

${ }^{123}$ A ello se suma la espuria y acientífica idea de la "naturalización" como sinónimo de "aceptada" de ciertas EEI objeto de la pesca recreativa, que sólo se predica de las especies que interesan, con la feble apoyatura de que llevan en nuestros ecosistemas algunas decenas de años o incluso algún siglo, lo que no deja de ser una fracción ridícula de tiempo en la escala evolutiva, como hemos indicado más arriba. Por tanto, no puede aceptarse el criterio de la Ley 9/1999, de 26 de mayo, de Conservación de la Naturaleza de Castilla-La Mancha, dado el carácter invasor y exótico de la fauna ajena de un medio acuático determinado. Dice esta Ley: "En sentido biogeográfico, la que sin tener el carácter de autóctona en la zona, haya sido introducida en tiempos históricos por el hombre, manteniendo actualmente una población estable en la misma y en equilibrio con el resto de la comunidad biológica". En cualquier caso, este concepto es ajeno a la Ley 42/2007, del Patrimonio Natural, que solo lo recoge como sinónimo de disecación de animales, a la vez que no se recoge en el RD 1628/2011, del Catálogo de EEI. 
cangrejo autóctono; el lucio ha eliminado buena parte de las poblaciones de salmónidos y ciprínidos autóctonos y sobrevive a campañas de erradicación en regiones como Castilla y León; la perca negra americana o black-bass ha esquilmado los ecosistemas acuáticos de la España mediterránea y ya se encuentra en Galicia. En la misma línea de incongruencia e ilegalidad se encuentra el arruí, que se protege precisamente en los lugares de la Península donde se practica su caza con cierta fama, Murcia, desde donde se ha expandido a las provincias limítrofes, mientras que lo mismo puede decirse del muflón. Mención aparte merece el caso del esturión exótico siberiano (Accipenser baerii) y del Adriático (Accipenser nacarii), cuyos escapes han ocasionado graves problemas sanitarios y ambientales en algunas cuencas españolas, con la introducción de la "necrosis hematopoyética infecciosa" o NHI ${ }^{124}$.

El tirar la toalla en los lugares donde medran estas especies no puede recogerse en una norma de esta índole bajo las presiones de entidades que se dedican a la explotación de esas EEI, y mucho menos contraviniendo las normas básicas de la potestad

\footnotetext{
${ }^{124}$ La NHI fue detectada por vez primera en España en el año 2005 en una piscifactoría andaluza de esturiones exóticos, enfermedad incluida en la Orden andaluza de 29 de noviembre de 2004, por la que se desarrollan las normas de ejecución de los programas nacionales de vigilancia, prevención, control y erradicación de las enfermedades de los animales en Andalucía (BOJA de 13 de diciembre de 2004). Vid. el RD 617/2007, de 16 de mayo, sobre enfermedades de los animales de declaración obligatoria y se regula su notificación.
}

La NHI es de declaración obligatoria en toda la UE cuando entró en vigor el RD 2459/1996, de 2 de diciembre, por el que se establece la lista de enfermedades de animales de declaración obligatoria y se da la normativa para su notificación, normativa regulada en hoy en día por el RD 617/2007, de 16 de mayo, que establece la lista de las enfermedades de los animales de declaración obligatoria y se regula su notificación, y actualizada por la Orden ministerial ARM/831/2009, de 27 de marzo, por la que se modifican los anexos I y II del RD 617/2007, de 16 de mayo, por el que se establece la lista de las enfermedades de los animales de declaración obligatoria y se regula su notificación. En cuanto a las medidas sanitarias de la acuicultura, esta NHI se recoge en el RD 1614/2008, de 3 de octubre, relativo a los requisitos zoosanitarios de los animales y de los productos de la acuicultura, así como a la prevención y el control de determinadas enfermedades de los animales acuáticos, reformado por el RD 1590/2009, de 19 de octubre. Esta normativa transpone una Directiva comunitaria de nada menos que del año 1982: la Directiva 82/884/CEE, de 21 de diciembre. La UE ha aprobado programas por la Decisión de 14 de diciembre de 2009 por la que se modifica la Decisión 2009/177/CE en lo que respecta a los programas de erradicación y la calificación de «libre de la enfermedad» de Estados miembros, zonas y compartimentos en relación con determinadas enfermedades de los animales acuáticos, en la que se muestra que España no está libre de la NHI. Con esta misma lógica, la Decisión de la Comisión de Europea de 2 de febrero de 2005 que modifica los anexos I y II de la Decisión 2002/308/CE, por la que se establecen listas de zonas y piscifactorías autorizadas en relación con la septicemia hemorrágica viral (SHV) y la necrosis hematopoyética infecciosa (NHI) ha establecido por exclusión el río Guadalquivir como zona de seguridad frente a la $\mathrm{NH}$, donde se ha constatado el escape de ejemplares de estos esturiones exóticos. Otra piscifactoría de esturiones exóticos, esta vez en Navarra, se encuentra en otra zona que ya se ha inundado, en el LIC del tramo medio del río Aragón; se estiman en cinco mil los ejemplares de más de diez kg. cada uno que allí se crían (Diario de Navarra de 25 de abril de 2011). 
reglamentaria de la Administración y las obligaciones internacionales y comunitarias contraídas por España ${ }^{125}$.

Otras cuestiones de interés las plantea el art. 8 del RD de EEI, sobre la necesidad de la autorización previa para liberar especies exóticas no incluidas en el Listado o el Catálogo; la exclusión de la previsiones anteriores respecto de especies objeto de cría o cultivo destinados al consumo, así como la importante medida de que "en ningún caso se podrán contemplar actuaciones o comportamientos destinados al fomento de las especies incluidas en el Listado y Catálogo. En particular, en el ejercicio de la pesca en aguas continentales quedará prohibida la utilización como cebo vivo o muerto de cualquier ejemplar de dichas especies, o de sus partes y derivados", puesto que la pesca, como hemos visto en este trabajo, es uno de los medios principales de las invasiones biológicas ${ }^{126}$, precepto que cuenta con múltiples antecedentes en la legislación pesquera autonómica. Como es obvio, los ejemplares del Catálogo obtenidos del medio natural no podrán ser devueltos, salvo por razones de investigación ${ }^{127}$. Por lo que respecta a las medidas de prevención y de lucha contra las EEI (art. 9 y ss.), este reglamento resume las medidas acordadas en instrumentos internacionales respecto del comercio, las aguas de lastre, trasvases intercuencas o los centros zoológicos ${ }^{128}$ y de cría y cultivo ${ }^{129}$, estableciéndose una red de alerta y vigilancia con el fin de aplicar las estrategias, las

\footnotetext{
${ }^{125}$ En especial, la responsabilidad medioambiental. La causación de un daño al hábitat y a las especies de estos ecosistemas está recogida en el art. 2, 3.2 y el Anexo II de la Ley 26/2007, de 23 de octubre, de Responsabilidad Medioambiental y el art. 8, 9 y 21 del RD 2090/2008, de 22 de diciembre, por el que se aprueba el Reglamento de desarrollo parcial de esta Ley. LOZANO, B. (dir.), Comentarios a la Ley de Responsabilidad Medioambiental, Thomson-Civitas, Cizur menor, 2008.

${ }^{126}$ BLANCO, R. y ZAMORA, R., Análisis de la pesca deportiva en Córdoba, Universidad de Córdoba. Córdoba, 1998. Sobre el peligro del cebo vivo y la expansión de EEI, la STSJ de Cataluña 662/1994, Sala de lo Contencioso-Administrativo, Sección $5^{\text {a }}$, de 28 de octubre, anula las disposiciones autonómicas de la Orden de Vedas que permitían su uso en ciertas competiciones, aludiendo expresamente a las especies invasoras.

${ }^{127}$ No obstante, es digna de crítica la obligación de que si son capturados o retenidos por un particular "sean entregados a las autoridades competentes, o proceder a su eliminación o retirada del medio natural según la normativa vigente". Verse en la tesitura de que al practicar la pesca se capture un pez exótico invasor y tener que llamar a la autoridad o acudir a un lugar de recogida de residuos es algo que quizás no debiera exigirse.

${ }^{128}$ RODRÍGUEZ-GUERRA, M. y GUILLÉN-SALAZAR, F., El parque zoológico, un nuevo aliado de la biodiversidad. Guía para la aplicación de la Ley 31/2003 de conservación de la fauna silvestre en parques zoológicos, Fundación Biodiversidad, Madrid, $2010^{2}$.

${ }^{129}$ Con la mención expresa por sus graves riesgos de las explotaciones de cría del visón americano y de cualquier cangrejo exótico. COWX, I. G. et al., Guidelines for environmentally sound practices for introductions and translocations in aquaculture. Report to the European Commission, Bruselas, 2009.
} 
cuales darán prioridad a las especies que supongan un mayor riesgo para las especies autóctonas y hábitats amenazados, especialmente las islas ${ }^{130}$.

Dado que las reacciones frente a la publicación del RD de EEI provinieron especialmente del mundo de la pesca recreativa basada en especies invasoras, apoyadas por algunas Comunidades Autónomas, se plantearon diversos recursos contenciosoadministrativos contra esta norma reglamentaria, los cuales han motivado la reciente publicación $^{131}$ del Acuerdo del Consejo de Ministros de 24 de febrero de 2012, que en la práctica supone el vaciamiento del contenido normativo del RD con la aceptación, contra toda evidencia científica ${ }^{132}$, de las quejas de estos sectores, al aceptar la anulación de los arts. 1, 4, 5, 7, 8, 10, la disposición transitoria segunda y el anexo II (el "listado"), lo que ha motivado la suspensión de la vigencia de la norma sobre ciertas especies ícticas en virtud de sendos Autos del Tribunal Supremo ${ }^{133}$.

A pesar de que se haya acordado la suspensión de los efectos del RD 1628/2011, de 14 de noviembre en relación con la trucha arco-iris y el black-bass, esto no altera lo estipulado en la Ley 42/2007 de Patrimonio Natural y Biodiversidad, en virtud del principio de jerarquía normativa, ya que simplemente se ha suspendido para unas especies la eficacia de una norma con rango reglamentario, lo cual no afecta a lo estipulado en una norma con rango superior, de Ley formal. Aun así, este Auto del TS ha sido malinterpretado por la Junta de Comunidades de Castilla-La Mancha, previa modificación de la Orden de Vedas de 2012, para autorizar ilegalmente la suelta de la trucha arco-iris mediante una Disposición Transitoria de la Orden de 27 de abril de 2012, de la Consejería de Agricultura, por la que se modifica la Orden de 18 de enero de 2012, de Vedas de Pesca. Por tanto, entendemos que estas sueltas de ejemplares de estas especies alóctonas y extrañas a los ecosistemas fluviales carecen de todo tipo de amparo

\footnotetext{
${ }^{130}$ Disposición adicional tercera del RD de EEI. Sobre los esfuerzos de erradicación de EEI en los ecosistemas insulares, vid. CONSEJO DE EUROPA, Group of Experts on Invasive Alien Species, Estrasburgo, 2011. MAYOL, J. et al., "Sa Dragonera, la mayor isla mediterránea (posiblemente) libre de roedores”, en Quercus, núm. 314, 2012.

${ }^{131}$ BOE de 19 de marzo de 2012.

${ }^{132}$ Vid. "Coto a las especies invasoras", El País de 31 de enero de 2012, firmado por Ríos con Vida, Greenpeace, WWF, SEO/Birdlife, Ecologistas en Acción, Amigos de la Tierra, Unipesca, Grupo Especialista en Invasiones Biológicas, Asociación Ibérica de Limnología y Sociedad Ibérica de Ictiología.

${ }^{133}$ ATS, Sala 3 $3^{\text {a }}$, Sección $3^{\text {a }}$, de 28 de marzo de 2012 (recurso 183/2012) en lo que respecta a las especies del Anexo I (el "catálogo") salvelino y black-bass, y de la trucha arco-iris y el hucho respecto del Anexo II (el "listado"). Este recurso ha sido interpuesto por la Federación Española de Pesca y Casting. De la misma Sala y Sección y con la misma fecha es el Auto de suspensión del recurso 184/2012, promovido por la Asociación Española de Blackbass (AEBASS), respecto de esta especie.
} 
legal y, de acuerdo con el art. 62. 3. e) de la Ley 42/2007, de 13 de diciembre, del Patrimonio Natural y de la Biodiversidad no se puede autorizar su aprovechamiento piscícola, siendo nulos de pleno Derecho los actos y las disposiciones administrativas de autorización de acuerdo con el art. 62 de la Ley 30/1992, del Régimen Jurídico de las Administraciones Públicas.

De todas formas y aun aceptándose el criterio de esta Orden de Vedas, la situación actual de la trucha arco-iris es la de ser una especie exótica per se, como nos dicen los estudios científicos y por lo tanto su suelta se regularía por el art. 8.3 del RD 1628/2011: "La liberación de una especie exótica no incluida en el Listado o en el Catálogo, y de acuerdo al artículo 52.2 de la Ley 42/2007, de 13 de diciembre, requerirá una autorización administrativa previa de la autoridad competente medioambiental, basada en un análisis de riesgos que así lo aconseje, según lo contemplado en el artículo 6.3”. Este análisis de riesgos contendrá al menos el nombre científico y vulgar de la especie; la mención específica a si se la especies se cría en cautividad; las actuaciones previstas a realizar en caso de escape o liberación accidental; la valoración de las probabilidades de su escape o liberación accidental, el establecimiento en la naturaleza, el convertirse en plaga, el causar daño medioambiental a las especies autóctonas, los hábitats o los ecosistemas, la agronomía o los recursos económicos asociados al uso del patrimonio natural, así como la viabilidad y técnicas de control, erradicación o contención; el conocimiento de la problemática, en caso de existir, causada por la especie en otros lugares y, finalmente, la existencia de medios eficaces para reducir riesgos de escape o liberación accidental. Como puede suponerse, nada de esto se cumple.

En cualquier caso, recordamos la vigencia de las disposiciones de la Ley del Patrimonio Natural y la Biodiversidad, que motivaron la intervención de la Fiscalía mucho antes de la entrada en vigor del RD de EEI, así como la vigencia del Derecho internacional y comunitario aplicable en esta materia. Como ya ha hecho notar la mejor doctrina iusambientalista, se ha de hacer respetar el principio jurídico de no regresión en la protección ambiental ${ }^{134}$.

\footnotetext{
${ }^{134}$ PRIEUR, M., El nuevo principio de no regresión en el Derecho Ambiental, Acto de Investidura del Grado de Doctor Honoris Causa, Universidad de Zaragoza, Zaragoza, 2010. LÓPEZ RAMÓN, F., "El principio de no regresión en la desclasificación de los espacios naturales protegidos en el Derecho Español”, Revista Aranzadi de Derecho Ambiental, núm. 20, 2011.
} 
El RD 1274/2011, de de 16 de septiembre, por el que se aprueba el Plan estratégico del patrimonio natural y de la biodiversidad 2011-2017, recoge en la Meta 2 relativa a proteger, conservar y restaurar la naturaleza en España y reducir sus principales amenazas, el Objetivo 2.4: "Establecer mecanismos para la prevención de la entrada, detección, erradicación y control de las especies exóticas invasoras", con un coste de diez millones de euros para este período, una cifra asumible teniendo en cuenta las pérdidas que ocasionan las EEI.

Para terminar, en el Derecho nacional, existen otras variadas normas que regulan las $\mathrm{EEI}^{135}$, a las que habrá de estar teniendo en cuenta las disposiciones de carácter básico vinculantes para las Comunidades Autónomas y el amplio conjunto normativo y el Derecho de la Biodiversidad aplicable a las EEI.

\footnotetext{
${ }^{135}$ Ley 5/2007, de 3 de abril, de la Red de Parques Nacionales; Ley 31/2003, de 27 de octubre, de conservación de la fauna silvestre en los parques zoológicos; RD 1082/2009, de 3 de julio, por el que se establecen los requisitos de sanidad animal para el movimiento de animales de explotaciones cinegéticas, de acuicultura continental y de núcleos zoológicos, así como de animales de fauna silvestre; RD 58/2005, modificado por el RD 471/2006 y OO.MM. APA/4139/2005, 725/2006 y 1242/2006 sobre medidas de protección contra la introducción y difusión en el territorio nacional y de la Comunidad Europea de organismos nocivos para los vegetales o productos vegetales; Orden ARM/2294/2011, de 19 de agosto, por la que se modifica la Orden ARM/2090/2011, de 22 de julio, por la que se establecen medidas provisionales de protección frente al caracol manzana Pomacea insularum y Pomacea canaliculata; Ley 4/2006, de 19 de mayo, de Conservación de la Naturaleza de Cantabria; Ley 1/2007, de 2 de marzo, de declaración del Parque Nacional de Monfragüe; Ley 11/2010, de 16 de noviembre, de pesca y acuicultura de Extremadura; Ley 22/2009, de 23 de diciembre, de ordenación sostenible de la pesca en aguas continentales de Cataluña; Ley 9/2008, de 9 de diciembre, de modificación de la Ley 6/1992, de 18 de diciembre, de protección de los ecosistemas acuáticos y de regulación de la pesca en Castilla y León; Ley 5/2011, de 10 de marzo, de Declaración del Parque Natural de la Sierra Norte de Guadalajara; Decreto legislativo $2 / 2008$, de 15 de abril, por el que se aprueba el Texto refundido de la Ley de protección de los animales de Cataluña; Decreto 213/2009, de 20 de noviembre, sobre el control de especies exóticas invasoras en la Comunidad Valenciana, o el Decreto 19/2011, de 10 de febrero, por el que se aprueban definitivamente las directrices de ordenación del territorio de Galicia. Vid. COLLAZOS STÜWE, A., "Comentarios al Decreto 213/2009, de 20 de noviembre, sobre el control de especies exóticas invasoras en la Comunidad Valenciana", Revista Aranzadi de Derecho Ambiental, núm. 20, 2011. Sobre las cuestiones sanitarias, es de aplicación el RD 1614/2008, de 3 de octubre, sobre los requisitos zoosanitarios de los animales y de los productos de la acuicultura, así como la prevención y el control de determinadas enfermedades de los animales acuáticos, modificado por el RD 1590/2009, de 16 de octubre. Estas normas transponen las Directivas comunitarias.
} 


\section{CONCLUSIONES}

Las EEI suponen una de las mayores amenazas para la conservación de la biodiversidad. Desde el punto de vista jurídico, existe desde hace mucho tiempo un asentado corpus doctrinal, legal y jurisprudencial que hacen de la biodiversidad autóctona un bien jurídico protegido y que goza del beneficio de la duda en caso de discrepancia, lo que conlleva a la falta de base jurídica de las medidas en pro de las especies exóticas e invasoras que a pesar de todo siguen adoptándose. Este arraigado acervo obliga tanto a particulares como a los poderes públicos no sólo a evitar que las EEI medren y expandan sus efectos, sino además a adoptar de modo fehaciente medidas que los limiten, reduzcan y eliminen, restaurando los hábitats y poblaciones de especies puestos en peligro o con su calidad mermada, entre los que destacan los vinculados a los ecosistemas acuáticos; por tanto, en caso de duda y en virtud del principio jurídico de precaución, siempre se ha de adoptar las medidas que vayan en contra de las EEI y a favor de la biodiversidad autóctona, sin arrumbar el principio jurídico de no regresión en la mejora de la calidad ambiental de nuestros ecosistemas.

Independientemente del contenido del RD de EEI de 2011, una norma reglamentaria que no puede imponerse a obligaciones contraídas por otras de rango jerárquico superior, este corpus jurídico impide la suelta de EEI en el medio natural, lo cual puede constituir además una actividad delictiva; a su vez, la búsqueda de amparo en la legalidad o al menos falta de prohibición de liberación de EEI en su día para proteger algunas de ellas, invalidaría de raíz la protección actual de la biodiversidad, teniendo en cuenta además que en algunos casos, como los cotos intensivos, se carece desde su origen de cobertura legal alguna.

En este trabajo se han expuesto suficientes criterios legales, jurisprudenciales y científicos suficientes para que los particulares y los poderes públicos reduzcan o incluso eliminen los efectos de las EEI, especialmente en los ecosistemas acuáticos, los más afectados por las invasiones biológicas derivadas de la pesca recreativa y la acuicultura ligada a ellas, dado que unas supuestas prácticas veteranas en el tiempo no pueden hacer frente al imperio de la Ley y a la evidencia científica. 


\section{BIBLIOGRAFÍA}

ALONSO GUTIÉRREZ, F., "La dispersión de los cangrejos rojo y señal en Castilla-La Mancha: ¿son válidas las medidas de gestión de especies invasoras a nivel geográfico de comunidad autónoma?", Foresta, núm. 47, 2010.

— “Austropotamobius pallipes”, Ríos con Vida, núm. 81, 2008.

ALLI TURRILlAS, J. C., La protección jurídica de la biodiversidad, Montecorvo, Madrid, 2008.

BARREIRA, A., et al., Medio ambiente y Derecho Internacional. Una guía práctica, Caja Madrid, Madrid, 2007.

BARTHOLOMEW, J.L. y RENO, P.W., "The history and dissemination of whirling desease", American Fisheries Society Symposium, núm. 29: 3-24, 2002.

BLANCO, R. y ZAMORA, R., Análisis de la pesca deportiva en Córdoba, Universidad de Córdoba. Córdoba, 1998.

BLASCO, J. Mª, BRUFAO, P. y RODRÍGUEZ C., Truchas invasoras. Informe sobre la ilegalidad de las sueltas masivas de trucha arco-iris (Oncorhynchus mykiss) y variedades alóctonas de trucha común (Salmo trutta) con fines de pesca deportiva, Ríos con Vida, El Tiemblo, 2010.

BRUFAO CURIEL, P., "Régimen jurídico de la pesca fluvial en Andalucía, ¿regreso a los derechos señoriales de pesca?", Revista Andaluza de Administración Pública, núm. $65,2007$.

— Subvenciones agrarias, desarrollo rural y medio ambiente, Comares, Granada, 2007.

— "El Estado de Derecho y el honor de la Justicia: El medio ambiente como termómetro jurídico de la ética pública", El Cronista del Estado Social y Democrático de Derecho, núm. 25, 2012.

BURGIEL, S., FOOTE, G., ORELLANA, M. y PERRAULT, A., Invasive alien species and trade: integrating prevention measures and international trade rules, The Center for International Environmental Law and Defenders of Wildlife, Washington, DC, 2006. 
CAPDEVILlA ARGÜELLES, L., et al., Especies exóticas invasoras. Diagnóstico y bases para la prevención y el manejo, Ministerio de Medio Ambiente. OAPN. Madrid, 2006.

CITES, Global strategy on invasive alien species, Washinton DC, 2000.

COLlAZOS STÜWE, A., “Comentarios al Decreto 213/2009, de 20 de noviembre, sobre el control de especies exóticas invasoras en la Comunidad Valenciana", Revista Aranzadi de Derecho Ambiental, núm. 20, 2011.

COMISIÓN EUROPEA e INSTITUTE FOR EUROPEAN ENVIRONMENTAL POLICY, Assessment to support continued development of the EU Strategy to combat invasive alien species, Bruselas, 2010.

COMISIÓN EUROPEA, Common Implementation Strategy for the Water Framework Directive (2000/60/EC). Guidance document $n^{\circ} 3$. Analysis of pressures and impacts, Luxemburgo, 2003.

- Hacia una estrategia de la UE sobre especies invasoras, COM (2008) 0789 final, Bruselas, 2008.

- Estrategia de la UE sobre biodiversidad hasta el 2020: Nuestro seguro de vida y capital natural, COM (2011) 244 final, Bruselas, 2011.

- A comparative assessment of existing policies on invasive species in the EU Member States and in selected OECD countries, Bruselas, 2011.

CONFEDERACIÓN HIDROGRÁFICA DEL DUERO., Manual de las especies exóticas invasoras de los ríos y riberas de la Cuenca Hidrográfica del Duero, León, 2011.

CONSEJO DE EUROPA, European charter on recreacional fishing and biodiversity, Estrasburgo, 2011.

— Group of Experts on Invasive Alien Species, Estrasburgo, 2011.

CONSEJO GENERAL DEL PODER JUDICIAL, El principio de precaución y su proyección en el Derecho administrativo español, Madrid, 2005.

COWX, I. G. et al., Guidelines for environmentally sound practices for introductions and translocations in aquaculture. Report to the European Commission, Bruselas, 2009. 
DE MOOR, A., Subsidizing unsustainable development. Undermining the earth with public funds, Earth Council, La Haya, 1997.

DIRECCIÓN GENERAL DE MEDIO AMBIENTE DE LA RIOJA et al., "Más sobre el castor europeo en la cuenca del Ebro", en Quercus, núm. 314, 2012.

DOADRIO , I. (dir.): Atlas y libro rojo de los peces continentales de España, Ministerio de Medio Ambiente y Consejo Superior de Investigaciones Científicas, Madrid, 2002.

ELVIRA, B., "Impacto y control de los peces exóticos introducidos en España", Granado Lorencio, C. (ed.), Conservación, recuperación y gestión de la ictiofauna continental ibérica, Estación de Ecología Acuática, Sevilla, 1997.

ENVIRONMENTAL LAW INSTITUTE, Invasive species control: a comprehensive model state law, Washington DC, 2004.

EPPO, Code of conduct on horticulture and invasive alien plants: proceedings of EPPO/Council of Europe Workshop, Oslo, 2009.

FANLO, A., "La pesca fluvial. Algunos criterios para articular su protección jurídica", Cosculluela, L. (coord..), Estudios de Derecho Público Económico, Civitas, Madrid, 2003.

GALERA RODRIGO, S., "Los instrumentos del derecho de la técnica: su consideración desde la técnica normativa", Rosado Pacheco, S. (dir.), Derecho europeo comparado sobre la Ley y el Reglamento, CEURA, Madrid, 2003.

GARCÍA DE ENTERRÍA, E. y FERNÁNDEZ RODRÍGUEZ, T.R., Curso de Derecho Administrativo, Madrid, Civitas. Madrid, $1989^{5}$.

GARCÍA DE JALÓN, D. y SCHMIDT, G. (coords.), Manual práctico para la gestión sostenible de la pesca fluvial, AEMS, Madrid, 1995.

GARCÍA URETA, A., Derecho europeo de la biodiversidad. Aves silvestres, hábitats y especies de flora y fauna, Iustel, Madrid, 2010.

GARRIDO, N., "Pesca fluvial”, Embid, A. (coord..), Diccionario de Derecho de Aguas, Iustel, Madrid, 2007.

GENOVESI P., SCALERA R., BRUNEL, S., SOLARZ W. y ROY D., Towards an information and early warning system for invasive alien species (IAS) threatening 
biodiversity in Europe, European Environment Agency, Tech. report 5/2010, Copenhague, 2010.

GENOVESI, P. y SCALERA, R., Towards a black list of invasive alien species entering Europe through trade, and proposed responses, Convention on the conservation of European wildlife and natural habitats, Estrasburgo, 2007.

GIL-ROBLES, A., "El ejercicio del derecho de pesca en aguas continentales: en torno a los cotos intensivos de pesca", Revista Española de Derecho Administrativo, núm. 7, 1975.

HALVERSON, A., An enterily synthetic fish. How rainbow trout beguiled America and overran the World, Yale University Press, New Haven, 2010.

HEYWOOD, V. y BRUNEL, S., Code of conduct on horticulture and invasive alien plants. Nature and Environment, Council of Europe Publishing, Estrasburgo, 2009.

HULME, P. E., PYSEK, P., NENTWIG, W. y VILA, M., "Will threat of biological invasions unite the European Union?”, Science, núm. 4-5, 2010.

JENKINS, P. T., GENOVESE, K. y RUFFLER, H., Broken screens: The regulation of live animal imports in the United States, Defenders of Wildlife, Washington DC, 2007. JORDANO, J., et al., Estudios sobre la Directiva 2004/35/CE de responsabilidad por daños ambientales y su incidencia en el ordenamiento español, Aranzadi, Cizur Menor, 2005.

LÓPEZ RAMÓN, F., "El principio de no regresión en la desclasificación de los espacios naturales protegidos en el Derecho Español", Revista Aranzadi de Derecho Ambiental, núm. 20, 2011.

LOZANO, B. (dir.), Comentarios a la Ley de Responsabilidad Medioambiental, Thomson-Civitas, Cizur menor, 2008.

MAYOL, J. et al., "Sa Dragonera, la mayor isla mediterránea (posiblemente) libre de roedores", en Quercus, núm. 314, 2012.

MUÑOZ LORENTE, J., "Los delitos relativos a la flora, fauna y animales domésticos (o de cómo no legislar en Derecho Penal y cómo no incurrir en despropósitos jurídicos)", Revista de Derecho Penal y Criminología, núm. 19, 2007. 
MYERS, NORMAN y KENT, JENNIFER (2001): Perverse Subsidies. How Tax Dollars Can Undercut the Environment and the Economy, Island Press, Washington DC, 2001.

PERRINGS C., WILLIAMSON M. y DALMAZZONE S. (eds.), The Economics of Biological Invasions, Edward Elgar, Cheltenham, 2000.

PERRINGS, C. MOONEY, H. y Williamson, M., (eds.), Bioinvasions and Globalization: Ecology, Economics, Management, and Policy. Oxford University Press, Oxford, 2010.

PLÁ I ZANUI, C., "Diversidad genética de la trucha autóctona española", Ríos con Vida, núm. 75, 2004.

PRADILLO, A., "El cangrejo de río autóctono vuelve a los ríos valencianos", Quercus, núm. 312, 2012.

PRIEUR, M., El nuevo principio de no regresión en el Derecho Ambiental, Acto de Investidura del Grado de Doctor Honoris Causa, Universidad de Zaragoza, Zaragoza, 2010 .

RAMOS VÁZQUEZ, J. A., “Comentario al artículo 333 del Código Penal”, en Faraldo Cabana, P. (dir.): Ordenación del territorio, patrimonio histórico y medio ambiente en el Código Penal y la legislación especial, Tirant lo Blanch, Valencia, 2011.

RICHARDSON, D. M. et al, "Naturalization and invasión of alien plants: concepts and definitions, Diversity and Distributions, núm. 6, 2000.

RODRÍGUEZ-GUERRA, M. y GUILLÉN-SALAZAR, F., El parque zoológico, un nuevo aliado de la biodiversidad. Guía para la aplicación de la Ley 31/2003 de conservación de la fauna silvestre en parques zoológicos, Fundación Biodiversidad, Madrid, 2010².

ROODMAN, D.M., Paying the piper. Subsidies, politics, and the environment, Worldwatch Institute, Washington DC, 1996.

SCALERA R., "How much is Europe spending on invasive alien species? "Biological Invasions, núm. 12(1), 2010.

SHINE C., WILLIAMS, N. y BURHENNE-GUILMIN, F., "Legal and institutional frameworks for invasive alien species", Mooney, H.A., J. McNeely, L.E. Neville, P.J. 
Schei, J.K. Waage (eds.), Invasive Alien Species: a new synthesis, Island Press, Washington DC, 2005.

SORIANO GARCÍA, J. E. y BRUFAO CURIEL, P., Claves de Derecho Ambiental II. Medio natural, biodiversidad y riesgos tecnológicos, Iustel, Madrid, 2011.

TEEB, The Economics of ecosystems and biodiversity for national and international policy makers, Earthscan, Londres, 2011.

TEIJEIRO LILLO, Ma E., "Calidad y seguridad de los productos acuícolas", Revista Aragonesa de Administración Pública, núm 28, 2006.

— Acuicultura marina: Régimen jurídico y ordenación ambiental, Iustel, Madrid, 2009. - Acuicultura marina: Mercado, consumo y sanidad animal, Iustel, Madrid, 2011. WWF, El trasvase Tajo-Segura. Lecciones del pasado, Madrid, 2003.

YOUNG, T. R., National and regional legislation for promotion and support to the prevention, control and erradication of invasive species, World Bank, Biodiversity Series, núm. 108, Washington DC, 2006. 